\title{
DCC mutation update: congenital mirror movements, isolated agenesis of the corpus callosum and developmental split brain syndrome
}

Ashley PL Marsh ${ }^{1}{ }^{2} *$, Timothy J Edwards ${ }^{3,4}$, Charles Galea ${ }^{5}$, Helen M Cooper ${ }^{3}$, Elizabeth C Engle $^{6-11}$, Saumya S Jamuar ${ }^{6-8,12,13}$, Aurélie Méneret ${ }^{14,15}$, Marie-Laure Moutard ${ }^{16-18}$, Caroline Nava $^{14,19}$, Agnès Rastetter ${ }^{14}$, Gail Robinson ${ }^{20}$, Guy Rouleau ${ }^{21,22}$, Emmanuel Roze ${ }^{14,15}$, Megan Spencer-Smith ${ }^{23,24}$, Oriane Trouillard ${ }^{14}$, Thierry Billette de Villemeur ${ }^{16,17,25,26}$, Christopher A Walsh ${ }^{6-9,11,12}$, Timothy W Yu ${ }^{6,11,12}$, IRC $^{5}$ Consortium $^{\S}$, Delphine Heron ${ }^{17,19}$, Elliott H Sherr ${ }^{27}$, Linda J Richards ${ }^{3,28}$, Christel Depienne ${ }^{14,19,29,30}$, Richard J Leventer ${ }^{2,31,32}$ and Paul J Lockhart ${ }^{1,2}$

* Correspondence to Ashley PL Marsh, Bruce Lefroy Centre for Genetic Health Research, Murdoch Children's Research Institute, Royal Children's Hospital, Parkville, Victoria, Australia.E-mail:ashley.marsh@mcri.edu.au

$\S$ Members of the International Research Consortium for the Corpus Callosum and Cerebral Connectivity $\left(I R C^{5}\right)$ are listed in the appendix.

\section{Grant Sponsors}

This work was funded in part by the National Health and Medical Research Council (NHMRC) Australia Project Grants (GNT1059666 to PJL and GNT1126153 to LR, EHS and RJL), the Campbell Edwards Trust, the Victorian Government's Operational Infrastructure Support Program, the Australian Government NHMRC IRIISS and the Repository Core for Neurological Disorders, Department of Neurology, Boston Children's Hospital, and NIH IDDRC 1 U54 HD090255. APLM was supported by an Australian Postgraduate Award, TJE was supported by a University of Queensland Research Scholarship, ER received research support from foundation Desmarest, LJR was supported by an NHMRC Principal Research Fellowship and PJL was supported by a NHMRC Career Development Fellowship (GNT1032364).

${ }^{1}$ Bruce Lefroy Centre for Genetic Health Research, Murdoch Children's Research Institute, Royal

Children's Hospital, Parkville, Victoria 3052, Australia.

${ }^{2}$ Department of Paediatrics, University of Melbourne, Parkville, Victoria 3052, Australia.

${ }^{3}$ The University of Queensland, Queensland Brain Institute, St Lucia, Brisbane, 4072, Australia.

${ }^{4}$ The University of Queensland, Faculty of Medicine, Herston, Brisbane, 4006, Australia.

${ }^{5}$ Drug Delivery, Disposition and Dynamics (D4), Monash Institute of Pharmaceutical Sciences,

Monash University, Parkville, Victoria, 3052 Australia.

${ }^{6}$ Division of Genetics and Genomics, Boston Children's Hospital, Boston, Massachusetts, USA.

This is the author manuscript accepted for publication and has undergone full peer review but has not been through the copyediting, typesetting, pagination and proofreading process, which may lead to differences between this version and the Version of Record. Please cite this article as doi: 10.1002/humu.23361.

This article is protected by copyright. All rights reserved. 
${ }^{7}$ Manton Center for Orphan Disease Research, Boston Children's Hospital, Boston, Massachusetts, USA.

${ }^{8}$ Howard Hughes Medical Institute, Boston Children's Hospital, Boston, Massachusetts, USA.

${ }^{9}$ Department of Neurology, Boston Children's Hospital and Harvard Medical School, Boston, Massachusetts, USA.

${ }^{10}$ Department of Ophthalmology, Boston Children's Hospital and Harvard Medical School, Boston, Massachusetts, USA.

${ }^{11}$ Program inMedical and Population Genetics, Broad Institute of Massachusetts Institute of Technology (MIT) and Harvard, Cambridge, Massachusetts, USA.

${ }^{12}$ Department of Rediatrics, Harvard Medical School, Boston, Massachusetts, USA.

${ }^{13}$ Department of Paediatrics, KK Women's and Children's Hospital, Paediatric Academic Clinical Programme, Duke-NUS Medical School, Singapore.

${ }^{14}$ INSERM, U 1127, CNRS UMR 7225, Sorbonne Universités, UPMC Univ Paris 06 UMR S 1127, Institut du Cerveau et de la Moelle épinière, ICM, F-75013, Paris, France.

${ }^{15}$ AP-HP, Hôpital de la Pitié-Salpêtrière, Département de Neurologie, F-75013, Paris, France.

${ }^{16}$ AP-HP, Hôpital Trousseau, service de neuropédiatrie, 75012 Paris, France.

${ }^{17}$ UPMC, GRC ConCer-LD, Sorbonne université, Paris France.

${ }^{18}$ Centre de référence "Neurogénétique", 75013 Paris France.

${ }^{19}$ AP-HP, Hôpital de la Pitié-Salpêtrière, Département de Génétique, F-75013, Paris, France.

${ }^{20}$ Neuropsychology Research Unit, School of Psychology, The University of Queensland, Brisbane QLD 4072, Australia.

${ }^{21}$ Department of Neurology and Neurosurgery, McGill University Health Center, Montreal, Quebec, H3A 2B4 Canada.

${ }^{22}$ Montreal Neurological Institute and Hospital, McGill University, Montréal, Quebec H3A 2B4, Canada.

${ }^{23}$ Clinical Sciences, Murdoch Children's Research Institute, Parkville, Victoria 3052, Australia.

${ }^{24}$ School of Psychological Sciences and Monash Institute of Cognitive and Clinical Neurosciences, Monash University Clayton Campus, Clayton Victoria 3800, Australia.

${ }^{25}$ Centre de Référence "déficiences intellectuelles de causes rares", 75013 Paris, France.

${ }^{26}$ INSERM U1141, 75019 Paris, France.

${ }^{27}$ Department of Neurology, UCSF Benioff Children's Hospital, San Francisco, California, USA.

${ }^{28}$ The University of Queensland, School of Biomedical Sciences, St Lucia, Brisbane, 4072, Australia.

${ }^{29}$ Département de Médicine translationnelle et Neurogénétique, IGBMC, CNRS UMR.

This article is protected by copyright. All rights reserved. 
${ }^{30}$ Laboratoires de génétique, Institut de génétique médicale d'Alsace, Hôpitaux Universitaires de Strasbourg, 67000 Strasbourg, France.

${ }^{31}$ Neuroscience Research Group, Murdoch Children's Research Institute, Parkville, Victoria 3052, Australia.

${ }^{32}$ Department of Neurology, University of Melbourne, Royal Children's Hospital, Parkville, Victoria 3052, Australia

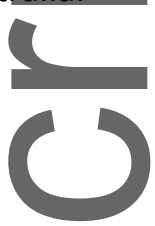

\section{Abstract}

The deleted in colorectal cancer $(D C C)$ gene encodes the netrin-1 receptor DCC, a transmembrane protein required for the guidance of commissural axons. Germline DCC mutations disrupt the development of predominantly commissural tracts in the central nervous system (CNS) and cause a spectrum of neurological disorders. Monoallelic, missense and predicted loss-of-function DCC mutations cause congenital mirror movements, isolated agenesis of the corpus callosum, or both. Biallelic, predicted loss-of-function DCC mutations cause developmental split brain syndrome. Although the underlying molecular mechanisms leading to disease remain poorly understood, they are thought to stem from reduced or perturbed Netrin-1 signaling. Here we review the 26 reported DCC mutations associated with abnormal CNS development in humans, including 14 missense and 12 predicted loss-of-function mutations, and discuss their associated clinical characteristics and diagnostic features. We provide an update on the observed genotype-phenotype relationships of congenital mirror movements, isolated agenesis of the corpus callosum and developmental split brain syndrome, and correlate this to our current understanding of the biological function of DCC in the development of the CNS. All 
mutations and their associated phenotypes were deposited in a locus specific LOVD (https://databases.lovd.nl/shared/genes/DCC).

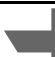

\section{Key Words}

DCC; Netrin-1; NTN1; mirror movements; agenesis of the corpus callosum; ACC; developmental split brain syndrome; horizontal gaze palsy with progressive scoliosis; axon guidance; mutation

\section{()}

\section{Background}

DCC (MIM\# 120470) encodes the DCC netrin-1 receptor protein, an evolutionarily conserved, single-pass transmembrane glycoprotein belonging to the immunoglobulin superfamily of cell adhesion molecules [Fearon, et al., 1990; KeinoMasu, et al., 1996]. DCC is located at 18q21.2 and spans chr18:52,340,17253,535,903 (GRCh38/hg38) [Hedrick, et al., 1994]. The canonical DCC transcript consists of 29 exons that encode a $159 \mathrm{kDa}$ (1447 amino acid) protein. DCC is a putative dependence receptor originally thought to function as a tumor suppressor gene, although this role has not been proven in vivo and remains controversial [Fearon, et al. 1990; Llambi, et al., 2001; Williams, et al., 2006; Bin, et al., 2015]. More recently, the role of DCC in the development of the central nervous system (CNS) was established [Keino-Masu, et al., 1996; Fazeli, et al., 1997; Finger, et al., 2002; Srour, et âl., 2010; Jamuar, et al., 2017; Marsh, et al., 2017].

$D C C$ is expressed by commissural axons and binds Netrin-1 (NTN1), a secreted protein encoded by the NTN1 gene (MIM\# 601614) which functions both locally and diffusely as a bifunctional guidance cue [Kennedy, et al., 1994; Keino-Masu, et al., 
1996; Blasiak, et al., 2017]. Both DCC and NTN1 are expressed throughout the developing mouse and human brain, with distinct but complementary spatial and temporal expression patterns [Shu, et al., 2000; Ren, et al., 2006; Harter, et al., 2010; Jamuar, et al., 2017]. DCC is required for the transduction of NTN1-induced attractive and long-range repulsive signaling in the coordinated outgrowth and guidance of commissural axons that cross the anatomical midline of the body [Chan, et al., 1996; Keino-Masu, et al., 1996; Hong, et al., 1999].

The development of commissural tracts is dependent on neurons forming synaptic connections with their target cells located on the opposite side of the CNS. To achieve this, neurons extend commissural axons tipped with a specialized, motile sensing device called a growth cone [Tessier-Lavigne and Goodman, 1996]. Growth cones express an array of axon guidance receptors such as DCC. The binding of a chemotactic (diffusible) or haptotactic (substrate-bound) guidance cue to an axon guidance receptor generates a permissive or non-permissive axonal outgrowth signal, or an attractive or repulsive directional response [Tessier-Lavigne and Goodman, 1996; Raper and Mason, 2010]. The signals transduced by axon guidance receptors converge to modulate the assembly of growth cone filamentous actin and cytoskeletal microtubules required for directing axon outgrowth and guidance towards or away from a guiding cell population [Luo, 2002; Kahn and Baas, 2016].

Monoallelic and biallelic germline DCC mutations disrupt commissural axon guidance [Srour, et al., 2010; Jamuar, et al., 2017; Marsh, et al., 2017; Welniarz, et al., 2017b]. These disruptions impair the normal development and function of tracts 
such as the corticospinal tract (CST) and corpus callosum (CC). Monoallelic DCC mutations cause congenital mirror movements (MMs, MIM\# 157600) in association with abnormal midline crossing of the CST, isolated agenesis of the CC (iACC, MIM\# 217990), or both [Srour, et al., 2010; Marsh, et al., 2017]. Alternatively, biallelic DCC mutations leading to predicted loss-of-function (LoF) cause developmental split brain syndrome (DSBS, MIM\# 617542), a more complex syndrome associated with agenesis of the corpus callosum (ACC) as well as widespread failure of commissural tracts throughout the rest of the CNS, with or without MMs [Jamuar, et al., 2017].

\section{Variant Database}

We created a new repository for all reported disease-associated $D C C$ sequence variants using the Leiden Open Variation Database (LOVD 3.0: $\underline{\text { http://databases,lovd.nl/shared/genes/DCC) }}$ [Fokkema, et al., 2011]. The International Research Consortium for the Corpus Callosum and Cerebral Connectivity (IRC5 , http://www.irc5.org) encourages users to register and submit data, including clinical and neuroimaging phenotypic data.

\section{Variant Nomenclature}

The nomenclature for DNA and protein sequence variants adheres to the guidelines of the Human Genome Variation Society (HGVS) [den Dunnen and Antonarakis, 2000]. Variant descriptions were based on the following Genbank reference sequences: NG_013341.2, NM_005215.3 and NP_005206.2. We utilized the Mutalyzer program (https://mutalyzer.nl/) to validate variant descriptions. At the time 
of publication, the DCC Locus Reference Genomic sequence (LRG_1107) was under curation and pending approval [MacArthur, et al., 2014].

\section{Variants}

To date, 26 unique DCC mutations have been associated with MMs, iACC and DSBS in 66 individuals from 25 unrelated families (Figure 1). There are 29 reported unaffected heterozygous mutation carriers; 11 confirmed carriers from 7 unrelated families assessed for MMs and brain abnormalities using magnetic resonance imaging (MRI) or computed tomography $(\mathrm{CT})$, and 18 carriers from 9 unrelated families that appear clinically unaffected but have not been assessed for MMs and brain abnormalities. There are no reported unaffected individuals with biallelic, predicted LOF DCC mutations.

Monoallelic or biallelic missense (14 out of $24 ; 58 \%$ ) and monoallelic predicted LoF (10 out of $24 ; 42 \%)$ DCC mutations may cause MMs, iACC, or both (Table 1). These include one case each where two heterozygous missense mutations were inherited in cis p.(Met1217Val;p.Ala1250Thr) or in trans p.(Gly470Asp);(p.(Gly803Arg) and a biallelic p.(GIn691Lys) mutation observed in conjunction with an interhemispheric cyst and modest learning difficulties [Méneret, et al., 2014a; Jamuar, et al., 2017; Marsh, et al., 2017]. Alternatively, biallelic, predicted LoF (2 out of 2; 100\%) DCC mutations cause DSBS. Germline transmission of the mutant allele, except for a p.(Gly803Arg) mutation that arose de novo, was confirmed in all pedigrees where parental genotypes were available [Méneret, et al., 2014a]. DCC-MMs and DCCIACC are both associated with reduced penetrance: MMs $\approx 42 \%$ penetrance and iACC $\approx 26 \%$ penetrance [Marsh, et al., 2017]. In contrast, DSBS appears to be fully 
penetrant. Monoallelic DCC mutations are also associated with variable expressivity and affected individuals within one family may present with MMs, iACC, or both [Marsh, et al, 2017]. All DCC residues altered by a missense mutation are conserved throughout vertebrate evolution, although it should be noted that Dcc has been lostin passeriformes and galliformes during bird evolution, and are either novel (8 out of $14 ; 57 \%$ ) or found at a minor allele frequency of less than $0.5 \%$ (6 out of 14 ; 43\%) in the Exome Aggregation Consortium (ExAC) (Supp. Table S1) [Friocourt, et al., 20171. Predicted LoF DCC mutations include nine frameshift mutations, two truncating mutations and an intragenic deletion encompassing exons 4 and 5 (Table 1).

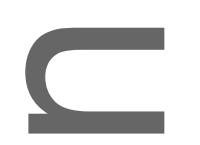

\section{Structure and Function}

DCC is composed of four structurally distinct, evolutionarily conserved regions: four extracellular immunoglobulin-like (lg-like) domains, six extracellular fibronectin type III-like (FN3) domains, a transmembrane domain, and an intracellular domain with three conserved P motifs (Supp. Figure S1) [Kolodziej, et al., 1996]. Each region of DCC appears to have a unique functional role required for the transduction of NTN1 signaling.

The distal $\mathrm{N}$-terminal region of DCC contains four lg-like domains and three interdomain linkers that together comprise 371 amino acids (residues 46-417). These domains fold into a horseshoe-like configuration that appears necessary for DCC to transduce NTN1-signaling [Chen, et al., 2013]. The proximal $\mathrm{N}$-terminal region of DCC contains six FN3 domains and five inter-domain linkers that together comprise 612 amino acids (residues 429-1041). Regions within the $4^{\text {th }}, 5^{\text {th }}$ and $6^{\text {th }}$ FN3 
domains bind NTN1 [Bennett, et al., 1997; Geisbrecht, et al., 2003; Finci, et al., 2014; Xu, et al., 2014]. This extracellular binding brings two DCC proteins into close proximity, enabling their intracellular domains to homodimerize and initiate the recruitment of multi-protein complexes required to transduce NTN1 signaling [Stein, et al., 2001; Mille, et al., 2009].

The DCC ligand, NTN1, is an extracellular protein belonging to the laminin superfamily and is composed of three structurally distinct regions: a laminin-like domain (LN), three laminin-type epidermal growth factor-like domains (LE) and a netrin-like domain (NTR) [Serafini, et al., 1994]. NTN1 has three distinct DCCbinding sites (binding site 1, 2 and 0; BS1, BS2 and BS0) (Figure 2). BS1 is located on the third LE of NTN1 and interacts exclusively with the $5^{\text {th }}$ FN3 domain of DCC. This site functions as a DCC-specific binding site and is stabilized by several hydrophobic interactions supported by a surrounding network of hydrogen bonds (Figure 3A) [Finci, et al., 2014]. BS2 is located on the first and second LE domains of NTN1 and interacts with a distinct region of the $5^{\text {th }}$ FN3 domain as well as the Nterminal region of the $6^{\text {th }}$ FN3 domain of DCC. This site functions as a generic binding site that can interact with receptors other than DCC [Finci, et al., 2014]. BS2 is predominantly stabilized by a group of sulfate and chloride anions that neutralize positively charged patches on NTN1 and DCC residues located at the binding interface (Figure 3B) [Finci, et al., 2014]. The adaptable nature of BS2 allows binding to the $1^{\text {st }}$ and $2^{\text {nd }} \lg$-like domains of members of the unc-5 netrin receptor (UNC5, MIM\# 603610) family of repulsive axon guidance proteins, which appear to have a higher affinity for BS2 relative to DCC [Leonardo, et al., 1997; Hong, et al., 1999; Geisbrecht, et al., 2003; Finci, et al., 2014]. As a result, UNC5 are able to 
outcompete DCC at BS2 and switch an attractive growth cone response (mediated via NTN1-induced DCC homodimerization) to a repulsive response (mediated via NTN1-induced DCC and UNC5 heterodimerization) [Hong, et al., 1999; Finci, et al., 2014; Grandin, et al., 2016]. In contrast to BS1 and BS2, BS0 is located on the LN of NTN1 and interacts with the $4^{\text {th }}$ FN3 domain of DCC [Xu, et al., 2014]. This NTN1 protein is different to the one simultaneously engaged at BS1 and BS2, but binds the same DCC protein occupied at BS1 (Figure 3C). The binding of DCC by a second NTN1 protein at BS0 is thought to generate a signaling cluster important for the transduction of a directional response towards or away from a guiding cell population [Finci, et al., 2015].

Taken together, these studies indicate that NTN1 forms two distinct binding clusters through BSO,BS1, and BS2 and that these clusters underpin its bifunctionality as an attractive and repulsive guidance cue. The first cluster involves the $4^{\text {th }}$ and $5^{\text {th }}$ FN3 domains of one DCC protein at BSO and BS1, while the second cluster involves the $5^{\text {th }}$ and $6^{\text {th }}$ FN3 domains of a second DCC protein or the $1^{\text {st }}$ and $2^{\text {nd }} \lg$-like domains of an UNC5 family member protein at BS2. However, it should be noted that the actual in vivo binding structure may differ as these studies utilized a recombinant NTN1 protein lacking its NTR domain and different truncated DCC fragments, both lacking the NTN1 binding region in its entirety [Finci, et al., 2014; Xu, et al., 2014].

The importance of the $4^{\text {th }}, 5^{\text {th }}$ and $6^{\text {th }}$ FN3 domains are highlighted by the significant enrichment of DCC missense mutations linked to MMs and/or IACC within these NTN1 binding regions compared with missense variants located in these domains in the ExAC (Figure 4 A-B) [Marsh, et al., 2017]. This enrichment is most significant for 
monoallelic, missense mutations linked to iACC (5 out of $9 ; 56 \%$ ) and suggests that missense mutations may cause disease through different, perhaps more complex mechanisms compared to those mutations leading to predicted LoF and haploinsufficiency. This may be due to reduced or perturbed NTN1-induced axon repulsionand/or attraction caused by dysfunction of the mutant DCC protein in both a mutant-mutant homodimer and wild-type-mutant homodimer complex. Additional studies are required to determine whether these missense alterations cause complete or partial LoF or perhaps gain-of-function as antimorphic, hypermorphic or neomorphic mutations. For instance, it remains to be determined whether mutant DCC proteins are stably expressed and trafficked to the plasma membrane or aberrantly sequestered in the cytoplasm like mutant NTN1 proteins [Méneret, et al., 2017]. Howeven absence of the DSBS phenotype in an individual with a biallelic p.(GIn691Lys) missense mutation suggests that these mutant proteins may retain some residualfunction [Jamuar, et al., 2017].

The DCC transmembrane domain comprises 24 amino acids (residues 1098 to 1122). To bind NTN1, DCC must correctly partition its transmembrane domain within the cell plasma membrane. The palmitoylation and localization of the transmembrane domain to lipid rafts (cholesterol- and sphingolipid-enriched membrane subdomains of the plasma membrane) has been demonstrated to be necessary for DCC to transduce NTN1-induced axon guidance and outgrowth [Guirland, et al., 2004; Herincs, et al., 2005].

The intracellular, C-terminal region of DCC contains 324 amino acids (residues 1123-1447) and is required to transduce NTN1 signals into appropriate growth cone 
responses. Within the $\mathrm{C}$-terminal region there are three conserved $\mathrm{P}$ motifs referred to as $\mathrm{P} 1$ (encoded by residues $1150-1167$ ), $\mathrm{P} 2$ (encoded by residues $1330-1365$ ) and P3 (encoded by residues 1424-1447) [Kolodziej, et al., 1996]. These P motifs are involved in numerous protein-protein interactions and phosphorylation cascades required for the intracellular transduction of NTN1 signaling [Hong, et al., 1999; Stein and Tessier-Lavigne, 2001; Li, et al., 2004; Ren, et al., 2004; Fothergill, et al., 2014]. For example, the NTN1-induced, intracellular homodimerization of the DCC P3 motifs initiates downstream signaling events that generate an attractive growth cone response [Stein et al., 2001; Li, et al., 2002; Li, et al., 2004; Liu, et al., 2004; Meriane, et al., 2004; Ren, et al., 2004; Ren, et al., 2008]. Alternatively, the NTN1induced, intracellular heterodimerization of the DCC P1 motif and the DCC binding (DB) motif of UNC5 family members initiates downstream signaling events that generate a long-range, repulsive growth cone response [Hong, et al., 1999; Keleman and Dickson, 2001; Li, et al., 2006; Norris, et al., 2014].

\section{Genotype-Phenotype Correlation}

Monoallelic frameshift and nonsense DCC mutations are predicted to result in haploinsufficiency via nonsense mediated mRNA decay or rapid turnover of the truncated protein, resulting in reduced NTN1 binding [Srour, et al., 2010]. This is in contrast to $D C C$ missense mutations that likely generate a full-length protein within the cell [Meriane, et al., 2004; Finci, et al., 2014]. DCC proteins carrying a missense mutation may be non-functional, hypomorphic or may have an altered function that imparts a dominant effect through perturbed NTN1 binding, receptor multimerization and/or downstream signaling [Meriane, et al., 2004; Finci, et al., 2014]. Monoallelic, 
truncating $D C C$ mutations predicted to result in haploinsufficiency are frequently associated with MMs (8 out of $10 ; 80 \%$ ) or MMs with iACC (2 out of $10 ; 20 \%$ ). DCC missense mutations are less frequently associated with MMs (5 out of $14 ; 36 \%$ ). Instead, the majority of these mutations are associated with iACC (7 out of 14;50\%) or MMs with iACC (2 out of $14 ; 14 \%$ ). This disparity may be due to developmental differences between the $\mathrm{CC}$ and the subcerebrally projecting neurons that comprise the CST. The neuronal populations that comprise each of these tracts are molecularly distinct and uniquely employ DCC and NTN1 signaling to reach their contralateral targets [Molyneaux, et al., 2007; Fothergill, et al., 2014]. Therefore, a missense or predicated LoF DCC mutation may differentially affect commissural versus subcerebral axon trajectories, thus leading to iACC, MMs or both [Marsh, et al., 2017]. Although these observations do support the hypothesis that distinct disease mechanisms contribute to $D C C$-MMs or $D C C$-iACC, additional functional investigations are required to confirm this correlation. These investigations could utilize in vivo techniques such as in utero electroporation or conditional gene knockout to study the effect loss or dysfunction of Dcc has on the outgrowth and guidance of axons extending from specific populations of projection neurons during development.

Monoallelic, missense mutations located within the NTN1 binding sites of DCC appear to be strongly associated with iACC [Marsh, et al., 2017]. Indeed, the majority of DCC mutations located within the $4^{\text {th }}$ and $5^{\text {th }}$ FN3 domains are associated with iACC (5 out of 6 ; $83 \%$ ). Interestingly, the p.(Val793Gly) and p.(Gly805Glu) missense mutations located directly within the NTN1 binding interface are associated with a more severe phenotype that features both iACC and MMs [Xu, et al., 2014; Marsh, et 
al., 2017]. Previous studies have shown a differential disruption to NTN1-induced axon attraction and repulsion dependent on the location of the mutated DCC residue within the NTN1 binding interface (Figure 4C) [Finci, et al., 2014]. Consequently, DCC mutations located within the NTN1 binding interface may cause more severe disruptions to commissural axon outgrowth and guidance that result in a phenotype that features both iACC and MMs. Overall, it appears that the majority of missense iACC mutations localize to the FN3 domains (7 out of $9 ; 78 \%$ ), highlighting the importance of these domains to DCC function and callosal development.

The observed structure of pedigrees with monoallelic, predicted LoF DCC mutations has suggested a sex-bias in MMs and iACC phenotype expression [Sharafaddinzadeh, et al., 2008; Srour, et al., 2009; Marsh, et al., 2017]. Indeed, within these pedigrees a significant proportion of males displayed MMs, whilst iACC was almost exclusively detected in females [Marsh, et al., 2017]. Sex differences in callosal morphology have previously been linked with testosterone levels during prenatal brain development [Moffat, et al., 1997; Chura, et al., 2010]. Consistent with these observations, RNAseq and RT-qPCR analyses have detected a significant dose-dependent increase in DCC expression in testosterone-treated neural stem cells deriyed from human embryonic stem cells [Marsh, et al., 2017]. These findings suggest that iACC may occur when the expression of DCC falls below a threshold level during CC development, as would occur more commonly in females. However, given the incomplete penetrance observed in both sexes, the phenotype must also be influenced by additional genetic, epigenetic and/or environment factors [Marsh, et al., 2017]. Furthermore, the sex-specific nature of this phenotype imbalance remains to be verified as reciprocal analyses utilizing estrogens have not been reported. 
Additional in vivo investigations are required to evaluate the potential impact the hormonal context during brain development has on DCC expression and whether it

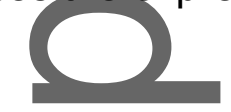

\section{Biological Significance}

Commissural axons form connections between the left and right sides of the brain that are required for the transfer and integration of information generated by sensory, motor and associative neurons. These connections are defined anatomically as either commissures or decussations. Whereas commissures cross the midline to form predominantly homotopic connections, decussations descend or ascend along the neuraxis before crossing the midline to form connections with different neuronal populations. For instance, axons within the CC arch over the lateral ventricles in a segregated, orderly manner to form predominantly homotopic connections with their target cells in the contralateral cerebral hemisphere [Zhou, et al., 2013]. These connections function by mediating higher-order brain processes and facilitating the integration of sensory and motor information between the two cerebral hemispheres [Paul, et al, 2007]. Within the CST, axons cross the midline at the medulla to form the pyramidal decussation between the brainstem and the spinal cord [Nathan, et al., 1990]. The connections formed by axons within the crossed CST facilitate the voluntary and unilateral movement of the contralateral distal limbs [Welniarz, et al., 2017a]. Several additional tracts within the brainstem are disrupted in DSBS [Jamuar, et al., 2017]. These appear to include the decussation of the superior cerebellar peduncles (also referred to as the commissure of Wernekinck) that connects the cerebellum to the midbrain, and the commissural tract linking the lateral 
abducens and medial occulomotor nerves, required for conjugate horizontal eye movement [Jen, 2008; Jamuar, et al., 2017].

The function of each commissural tract is underpinned by the transcriptionally distinct neuronal subtypes that comprise it [Molyneaux, et al., 2007; Harada, et al., 2016]. For instance, the CC is formed from pioneer axons extending from neurons in the cingulate cortex and follower axons extending from callosal projection neurons located within layers II/III and Va of the cerebral cortex [Fame, et al., 2011]. In comparison, the CST is comprised of an array of axons extending from subcerebrally projecting neurons situated within layer $\mathrm{Vb}$ of the cortex [Dum and Strick, 1991; Harwell, etal., 2012]. Notably, the tracts associated with the brainstem originate from diverse nuclei. For example, the transverse pontocerebellar projections arise from pontine nuclei while cranial nerves originate from nuclei located throughout the midbrain, pons and medulla. To reach their contralateral targets, these neuronal subtypes extend axons that express a unique repertoire of receptors, including DCC, on their growth cones [Dickson and Zou, 2010; Evans and Bashaw, 2010]. The tightly regulated, spatiotemporal expression of axon guidance receptors and their ligands control the development of tracts such as the CC and CST [Chedotal and Richards, 2010]. As highlighted below, our understanding of the development of these tracts and the associated role of DCC and NTN1 signaling in humans has been predominantly informed by the study of these biological processes in mice.

The formation of the $\mathrm{CC}$ is complex and dependent on the execution of several developmental steps. Briefly, these include midline patterning and remodeling of the interhemispheric fissure by astroglia to create a permissible substrate for 
commissural axons to cross the midline [Silver, et al., 1982; Hayhurst, et al., 2008; Okada, et al., 2008; Gobius, et al., 2016]; secretion of guidance cues by populations of glia and neurons situated around the midline [Shu and Richards, 2001; Shu, et al., 2003; Unni, et al., 2012]; pioneering of the callosal tract by axons extending from neurons in the cingulate cortex [Rash and Richards, 2001]; and fasciculation of callosal axons with pioneer axons as they grow towards and across the midline [Koester and O'Leary, 1994; Rash and Richards, 2001]. Dcc and Ntn1 are required for the normal development of the CC and their loss or dysfunction in mice is associated with complete ACC [Serafini, et al., 1996; Fazeli, et al., 1997; Finger, et al., 2002]. While both pre-crossing pioneer and callosal axons express Dcc, only the former axonal population appears to be attracted towards the midline by Ntn1 [Shu, et al., 2000; Fothergill, et al., 2014]. Instead, it has been shown that pre-crossing callosal axons utilize Dcc and Ntn1 signaling to attenuate the repulsive signaling of Robo1 and Slit2 (another axon guidance receptor-ligand pair) to approach and cross the midline [Stein and Tessier-Lavigne, 2001; Fothergill, et al., 2014]. The expression of Dcc in post-crossing callosal axons is subsequently downregulated, thereby restoring the repulsive effect of Robo1 and Slit2 signaling to direct axons away from the midline and towards their targets in the contralateral cerebral hemisphere [Shu, et al., 2000; Fothergill, et al., 2014].

The subcerebrally projecting neurons that comprise the CST mainly originate from the primary motor and premotor areas of the cortex and follow a stereotyped route to innervate their targets in the spinal cord [Dum and Strick, 1991]. During development, axons from these projection neurons converge and descend through the internal capsule and cerebral peduncles of the midbrain before entering the 
ventral brainstem where they form the medullary pyramids. Most CST projections then cross the midline in the caudal region of the medulla to form the pyramidal decussation, before projecting inferiorly in the spinal cord to synapse with lower motor neurons or interneurons in the ventral spinal cord to facilitate voluntary movement of the limbs [Welniarz, et al., 2017a]. Dcc is required for the normal development of the CST in mice and Dcc dysfunction is associated with a failure of the CST to cross the midline at the level of the pyramidal decussation [Finger, et al., 2002; Welniarz, et al., 2017b]. However, Dcc does not appear to be expressed in the brainstem CST of mice as it is significantly downregulated in the distal portion of the axon that grows beyond the internal capsule [Shu, et al., 2000; Finger, et al., 2002]. Interestingly, the function of Dcc in the development of the CST was reported to be non-cell autonomous as conditional gene knockout of Dcc in the cortex (and therefore the CST) caused ACC but not a failure of the CST to cross the midline [Welniarz, et at, 2017b].

In the brainstem and spinal cord, Dcc is present on commissural axons which are guided circumferentially from the dorsal roof plate towards the ventral floor plate (where midline crossing occurs) in response to Ntn1 [Holley, 1982; Tessier-Lavigne, et al., 1988; Yee, et al., 1999; Dominici, et al., 2017; Varadarajan, et al., 2017]. The attractive response of these commissural axons to Ntn1 is regulated by Dcc in partnership with Robo3, another axon guidance receptor required for normal development of the hindbrain and spinal cord [Marillat, et al., 2004; Sabatier, et al., 2004; Chen, et al., 2008; Zelina, et al., 2014]. Pioneering studies utilizing embryonic chick spinal cord demonstrated that this axonal navigation is reliant on a ventraldorsal gradient of Ntn1 diffused from the floor plate [Kennedy, et al., 1994]. 
Subsequent studies in mice also detected a similar graded distribution of Ntn1 extending from the floor plate, supporting the observation that Ntn1 functions as a long-range diffusible chemoattractant [Serafini, et al., 1996; Kennedy, et al., 2006]. However, recent reports have revised this model by demonstrating that Ntn1 produced by neural progenitors in the ventral ventricular zone of hindbrain and spinal cord neuroepithelium are essential for commissural axon extension towards the ventral midline in embryonic mice [Dominici, et al., 2017; Varadarajan, et al., 2017; Yamauchi, et al., 2017]. These reports propose that in mice commissural axons are directed via Dcc-dependent haptotaxis towards the ventral midline by Ntn1 produced and deposited at the pial surface of the hindbrain and spinal cord, not via a diffusible gradient of Ntn1 emanating from the floor plate [Dominici, et al., 2017; Varadarajan and Butler, 2017; Varadarajan, et al., 2017; Yamauchi, et al., 2017]. Therefore, regardless of how Ntn1 is presented to axons, it is clear that it functions to direct Dcc-expressing commissural axons towards the ventral midline of the hindbrain and spinal cord during development.

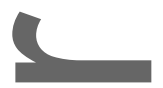

\section{Clinical Relevance}

MMs are involuntary movements on one side of the body that mirror voluntary movements made on the opposite side [Cincotta and Ziemann, 2008]. DCC-MMs commonly present in infancy or early childhood and persist stably into adulthood [Srour, et al., 2009; Srour, et al., 2010; Depienne, et al., 2011; Méneret, et al., 2014a; Franz, et al., 2015; Marsh, et al., 2017]. DCC-MMs manifest in the fingers and hands but may also be present in the forearms, toes and feet in a subset of affected individuals (Supp. Table S2) [Srour, et al., 2010; Méneret, et al., 2014a; 
Marsh, et al., 2017]. With effort, some affected individuals can partly suppress these involuntary movements [Srour, et al., 2009]. Individuals with DCC-MMs exhibit a range of functional disabilities besides difficulties in fine bimanual activities. These include fatigue, spontaneous muscle contractions and pain in the upper limbs during extended-manual activities such as writing, as well as general clumsiness and compensatory maneuvers to inhibit involuntary movements [Depienne, et al., 2011; Méneret, et al., 2014a; Meneret, et al., 2015; Marsh, et al., 2017]. As a result, DCCMMs may preclude affected individuals from professions and social activities that demand sustained or complex bimanual coordination. Individuals with DCC-MMs do not appear to exhibit any additional clinical manifestations and have a normal developmental outcome [Sharafaddinzadeh, et al., 2008; Srour, et al., 2009; Srour, et al., 2010; Dépienne, et al., 2011; Méneret, et al., 2014a; Franz, et al., 2015; Meneret, et al., 2015; Marsh, et al., 2017; Welniarz, et al., 2017b]. However, only a subset of individuals diagnosed with DCC-MMs are reported to have undergone brain imaging (12 out of 42; 29\%) and formal neuropsychological evaluation (2 out $42 ; 5 \%)$ and therefore the phenotypic spectrum of DCC-MMs remains to be defined [Marsh, et al., 2017].

DCC-MMs are observed in association with midline axon guidance defects, evidenced by decreased crossing of descending corticospinal motor projections at the pyramidal decussation [Marsh, et al., 2017; Welniarz, et al., 2017b]. This reduction of crossed projections occurs in conjunction with a relative, reciprocal increase of uncrossed projections [Marsh, et al., 2017; Welniarz, et al., 2017b]. Concordantly, unilateral transcortical stimulation of the primary hand motor area elicits both normal, contralateral and abnormal, ipsilateral motor evoked potentials in 
individuals with DCC-MMs [Cincotta, et al., 1994; Srour, et al., 2010; Welniarz, et al., 2017b]. As a result, DCC-MMs are thought to originate from the bilateral transmission of motor commands through normally crossed and abnormally uncrossed, fast-conducting CST projections in the spinal cord [Srour, et al., 2010; Welniarz, et al., 2015; Welniarz, et al., 2017b].

Individuals with monoallelic, missense DCC mutations may also present with iACC, with or without MMs [Marsh, et al., 2017]. ACC describes the partial or complete absence of the CC and is characterized by the failure of callosal axons to cross the midline. Apart from the abnormalities typically expected to be associated with ACC, such as the absence of the hippocampal commissure and cingulate gyrus and dysmorphic lateral ventricles or colpocephaly, individuals with iACC do not present with additional brain abnormalities [Kuker, et al., 2003; Cesaretti, et al., 2016]. Individuals with $D C C$-iACC may present with complete iACC (14 out of $19 ; 74 \%$ ) or partial iACE (5 out of 19;26\%) [Marsh, et al., 2017]. Approximately half of these individuals also present with MMs (9 out of $19 ; 47 \%$ ), which suggests that DCC-iACC may frequently present as part of a global disorder of midline crossing [Parrish, et al., 1979; Paul, et al., 2007; Marsh, et al., 2017]. Other callosal abnormalities such as hypoplasia (a uniformly thin CC) and/or dysplasia (abnormal CC shape) have not been observed in individuals with DCC-iACC [Marsh, et al., 2017]. Individuals with $D C C$-iACC show no consistent additional gross brain abnormalities in the posterior commissure, ventricular system, cerebral cortex, white matter, hippocampi, brainstem, basal ganglia, cerebral and cerebellar peduncles, cerebellar vermis and hemispheres, optic chiasm, and pituitary gland (Figure 5) [Marsh, et al., 2017]. However, the anterior commissure of some DCC-iACC individuals may be enlarged 
[Marsh, et al., 2017]. Enlargement of the anterior commissure is also observed in a minority of individuals with ACC and has been suggested to represent a compensatory mechanism to maintain connectivity between the cerebral hemispheres [Barr and Corballis, 2002; Hetts, et al., 2006].

The clinical manifestations of DCC-iACC vary, but they are generally associated with a favorable development outcome with no intellectual disability [Marsh, et al., 2017] (Supp. Table S2). Still, individuals with DCC-iACC do commonly exhibit typical neurobehavioral consequences associated with ACC, such as impairments in emotional and social functioning in addition to attention, language, visuospatial and literacy and numeracy deficits [Paul, et al., 2007; Sotiriadis and Makrydimas, 2012; Marsh, et al., 2017].

Biallelic, DCC mutations leading to predicted LoF are associated with DSBS, a complex syndrome associated with a broad disorganization of white-matter tracts throughout the CNS [Jamuar, et al., 2017]. The features of DSBS include absence of all commissures (including the $\mathrm{CC}$, anterior and posterior), brainstem defects (including hypoplasia of the pons and midbrain), horizontal gaze palsy and progressive scoliosis with a variable age of onset (Figure 5).

Several features of DSBS overlap with HGPPS1 (MIM\# 607313), a congenital syndrome caused by biallelic mutations in the axon guidance receptor ROBO3 (MIM\# 608630) [Jen, et al., 2004; Chan, et al., 2006; Sicotte, et al., 2006]. Robo3 is a functional, intracellular binding partner of Dcc, expressed by commissural axons in the brainstem and spinal cord [Marillat, et al., 2004; Sabatier, et al., 2004; Zelina, et al., 2014]. The overlapping feature of horizontal gaze palsy in DSBS and HGPPS1 
affected individuals appears to originate from hindbrain midline axon guidance defects in tracts that control conjugate horizontal eye movement [Jen, et al., 2004; Chan, et al., 2006; Sicotte, et al., 2006; Renier, et al., 2010; Jamuar, et al., 2017]. The pathogenesis of progressive scoliosis in both these disorders is unknown but may stem from defective spinal commissural interneurons or abnormal development of extrapyramidal projections [Jen, et al., 2004; Rabe Bernhardt, et al., 2012; Jamuar, et al., 2017]. Diffusion MRI of one DSBS individual with a biallelic p.(Val263Alafs*36) mutation revealed several tract defects, including absence of the decussation of the superior cerebellar peduncles and transverse pontocerebellar projections [Jamuar, et al., 2017]. These commissural defects are also observed in individuals with HGPPS1 [Sicotte, et al., 2006]. Individuals with DSBS may also present with MMs, which are associated with the reduced midline crossing of descending CST projections at the pyramidal decussation [Jamuar, et al., 2017]. This is in contrast to individuals with HGPPS1 who do not display MMs, a feature attributed to an uncrossed CST leading to reversed lateralization of motor control [Jen, et al., 2004]. It is currently unknown why some individuals with DSBS and complete loss of DCC do not present with MMs. However, like HGPPS1, this may be due to a complete, rather than partial, failure of the descending CST to cross the midline. The other major clinical manifestations of DSBS include intellectual disability, global developmental delay and hypotonia (Supp. Table S2) [Jamuar, et al., 2017]. Individuals with DSBS have a poor developmental outcome compared to individuals with $D C C$-iACC, likely attributed to additional brain abnormalities affecting the formation of other commissural tracts [Jamuar, et al., 2017; Marsh, et al., 2017]. 


\section{Diagnostic Strategies}

The clinical assessment and diagnosis of MMs is commonly based on the Woods and Teuber severity scale developed in 1978 [Woods and Teuber, 1978]. The assessment typically consists of three different hand motor tasks. The level of MMs visible in the mirror hand is scored on a scale between 1 - barely discernible repetitive movement and 4 - movement equal to that expected for the intended hand [Woods and Teuber, 1978]. The majority of individuals with DCC-MMs score between 2 (slight but unsustained or stronger, but briefer, repetitive movement) and 3 (strong and süstained repetitive movement). Recently, accelerometer gloves were utilized to quantitatively evaluate MMs in a multiplex MMs family with a monoallelic, p.(Pro551Leufs*26) DCC mutation [Franz, et al., 2015]. These gloves detect subtle movement, in contrast to electromyography that measures the electrical activity produced by skeletal muscle [Franz, et al., 2015]. Interestingly, the accelerometer gloves led to the diagnosis of subclinical MMs in two additional family members initially diagnosed as unaffected carriers following standardized neurological assessment. The current penetrance of DCC-MMs is approximately $42 \%$ [Marsh, et al., 2017]. In light of these findings, it appears likely that a proportion of clinically unaffected mutation carriers have subclinical MMs and that the true prevalence of $D C C$-MMs may be higher. It remains to be determined whether subclinical DCCMMs are associated with a similar, or perhaps less severe, failure of the CST to cross the midline.

Brain abnormalities such as ACC can be readily identified utilizing ultrasonography, $\mathrm{CT}$ and MRI. MRI is considered the gold standard for the diagnosis of ACC because of its superior sensitivity and ability to differentiate iACC and complex ACC (ACC 
with additional brain abnormalities) [Rapp, et al., 2002; Wright, et al., 2010; Tercanli and Prufer, 2016]. The distinction of the latter is important in a prenatal setting as individuals with iACC generally have a favorable developmental outcome compared to those with complex ACC [Sotiriadis and Makrydimas, 2012; Edwards, et al., 2014; D'Antonio, et al., 2016; des Portes, et al., 2017]. Likewise, individuals with DCCiACC havera favorable developmental outcome while individuals with DSBS have a poor developmental outcome. The current penetrance of $D C C$-iACC is approximately 26\% [Marsh, et al., 2017]. However, brain imaging studies have not been completed for the majority of affected individuals originating from DCC-MMs-only families (29 out of $36 ; 81 \%$ ). Given its mild clinical phenotype and concomitance with DCC-MMs, it is probable that further brain imaging studies will identify $D C C$-iACC in a proportion of these mutation-positive individuals. Like DCC-MMs, the true prevalence of DCCiACC is likely to be higher than current estimates.

Genetic screening for monoallelic DCC mutations is recommended for individuals presenting with MMs, IACC or both, in the absence of intellectual disability. Alternatively, screening for biallelic DCC mutations with predicted LoF is recommended for individuals presenting with characteristic features of DSBS, including horizontal gaze palsy, ACC, brainstem defects and progressive scoliosis. Direct sequencing of coding exons and flanking intronic regions using germline DNA is advised when screening for DCC mutations. Given the mild clinical phenotype and high rates of incomplete penetrance associated with $D C C$-MMs and DCC-iACC, cascade testing should be considered for all extended family members at risk of inheriting a mutant allele. Differential genetic diagnoses for DCC-MMs include NTN1 and RAD51 (MIM\# 179617) [Depienne, et al., 2012; Méneret, et al., 2014a; Méneret, 
et al., 2017]; for DCC-iACC include CDK5RAP2 (MIM\# 608201, although only one family has been described to date [Jouan, et al., 2016]); and for DSBS include ROBO3 (note: individuals with HGPPS1 do not suffer from intellectual disability and have normal forebrain commissures, consistent with the predominant role of $R O B O 3$ in the developing hindbrain and spinal cord) [Jen, et al., 2004; Chan, et al., 2006; Sicotte, et al.,2006]. However, the low diagnostic yield of genetic screening studies indicates that additional MMs and IACC disease genes remain to be identified and therefore mutations in DCC, NTN1, RAD51 and CDK5RAP2 will not always be identified in individuals with these phenotypes [Méneret, et al., 2014a; Méneret, et al., 2014b; Franz, et al., 2015; Jamuar, et al., 2017; Marsh, et al., 2017; Méneret, et al., 2017]

\section{Variants of Unknown Significance}

The classification and clinical interpretation of a DCC sequence variant is challenged by the variable expressivity of monoallelic DCC mutations and the incomplete penetrance associated with DCC-MMs and DCC-iACC. It may also be complicated by phenotypic heterogeneity and the identification of other potential pathogenic variants in an individual. In this context and in the absence of sufficient evidence to classify a DCC variant as pathogenic or not, it is recommended to report such a genetic alteration as a variant of unknown significance (VUS).

To illustrate these issues, we describe individual N-0083-01 with two novel, monoallelic VUS predicted to be damaging by most in silico tools: a maternally inherited NM_005215.3:c.916G>A:p.(Gly306Arg) DCC alteration and a de novo NM_001270399.1:c.1246G>A:p.(Gly416Ser) TUBA1A (MIM\# 602529) alteration 
(Supp. Table S3) [Jamuar, et al., 2017]. The individual has complete ACC with a small pons and small inferior aspect of the midbrain, but no definite cortical malformation as would be expected to result from a pathogenic TUBA1A mutation [Keays, et al., 2007]. However, the individual does not exhibit the mild clinical manifestations associated with DCC-iACC. Instead, she has global developmental delay and severe cognitive impairments with significant emotional and behavioral problems in addition to spastic diplegia, strabismus and cortical visual impairment (Supp. Table S4). As exemplified by this case, additional disease modeling and physiologically relevant functional assays are required to better inform the classification and clinical interpretation of DCC sequence variants, particularly for those causing missense alterations.

\section{Future Prospects}

Mutations in $D C C$ disrupt the development of predominantly commissural tracts in the CNS and cause a spectrum of neurological disorders ranging from MMs and IACC with a normal or favorable developmental outcome, to DSBS with a poor developmental outcome. These findings are consistent with previously reported animal models and support the notion that DCC, in partnership with NTN1, functions as a master regulator of commissural axon guidance [Fazeli, et al., 1997; Finger, et al., 2002; Varadarajan, et al., 2017; Welniarz, et al., 2017b]. Future investigations into the underlying molecular mechanisms leading to these disorders will strengthen current genotype-phenotype correlations. However, insightful correlations will be dependent on the multidisciplinary phenotyping of affected individuals, employing standardized neurological assessment, formal neuropsychological evaluation and 
brain imaging studies. Utilization of advanced neuroimaging modalities, such as diffusion MRI-based tractography and functional MRI, will also aid our understanding of how the brains of these affected individuals is wired in the context of DCC dysfunction or LOF during development. We anticipate the DCC locus specific LOVD will function as a central data repository that will assist researchers to establish these important genotype-phenotype correlations.

\section{wledgements}

The authors gratefully acknowledge the participation of the patients and their families in these studies and the support of the Australian Disorders of the Corpus Callosum (AusDoCC) organization, as well as the generous financial support of the Lefroy and Handbury families. The authors also acknowledge and thank Ivo Fokkema and Johan T-den Dunnen from the Leiden University Medical Center for their assistance in establishing the DCC LOVD. This work was funded in part by the National Health and Medical Research Council (NHMRC) Australia Project Grants (GNT1059666 to PJL and GNT1126153 to LJR, EHS and RJL), the Campbell Edwards Trust, the Victorian Government's Operational Infrastructure Support Program, the Australian Government NHMRC IRIISS and the Repository Core for Neurological Disorders, Department of Neurology, Boston Children's Hospital, and NIH IDDRC 1 U54 HD090255. APLM was supported by an Australian Postgraduate Award, TJE was supported by a University of Queensland Research Scholarship, LJR was supported by an NHMRC Principal Research Fellowship and PJL was supported by a NHMRC Career Development Fellowship (GNT1032364).

Disclosure statement: AM received travel funding from Zambon Company and AbbVie tnc. ER has received research support from Merz-Pharma, Orkyn, Aguettant, IP Santé, Ultragenix, IPSEN, Association Française pour l'Hémiplégie Alternante, AMADYS; served on scientific advisory boards for Orkyn, Ultragenix, Retrophin and 
Merz Pharma; received speech honoraria from Orkyn, Aguettant, Merz Pharma and Ultragenix; and received travel funding from the Dystonia Coalition, the Dystonia Medical Research Foundation, the Movement Disorders Society, and the European Academy of Neurology. SSJ is co-founder of Global Gene Corporation. TWY is cofounder of and part-time consultant to Claritas Genomics.

\section{Appendix}

Members of the International Research Consortium for the Corpus Callosum and Cerebral Connectivity (IRC ${ }^{5}$, http://www.irc5.org) are listed as follows: Vicki Anderson (Murdoch Children's Research Institute, Melbourne, Australia); Tania AttiéBitach (Hospital Necker-Enfants Malades and Université Paris Descartes, Paris, France); Warren Brown (Travis Research Fuller Institute, Fuller Graduate School of Psychology, Pasadena, CA USA); Christel Depienne (Université Paris Descartes, Paris, France); Delphine Heron (Université Paris Descartes, Paris, France); Roberto Lent (Federal University of Rio de Janeiro, Brazil); Richard J Leventer (Murdoch Children's Research Institute, Melbourne, Australia); Paul J Lockhart (Murdoch Children's Research Institute, Melbourne, Australia); Simone Mandelstam (Florey Neurosciences, Melbourne, Australia); George McGillivray (Murdoch Children's Research Institute, Melbourne, Australia); Lynn K Paul (California Institute of Technology, Pasadena, CA , USA); Linda J Richards (The University of Queensland, Queensland Brain Institute and School of Biomedical Sciences, Brisbane, Australia); Gail Robinson (The University of Queensland, School of Psychology, Brisbane, Australia); Elliott H Sherr (University of California, San Francisco, USA); Fernanda Tovar-Moll (Federal University of Rio de Janeiro and D'Or Institute for Research and Education).

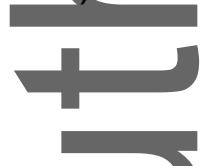

\section{Supplementary Figure and Table Legends}

Supp. Figure S1 - (A) Domain architecture of DCC containing four immunoglobulin-like (Iglike) domains (orange), six fibronectin type III-like (FN3) domains (green), a transmembrane (TM) domain (yellow), and an intracellular domain with three conserved P motifs (blue). (B) 
The percentage denotes the level of evolutionary conservation of residues located in each functional domain compared to the human reference sequence (NP_005206.2).

Supp. Table S1 - Multiple sequence alignment of orthologous DCC proteins demonstrating high evolutionary conservation of residues altered by missense mutations (highlighted in green).

Supp. Table S2 - Clinical summary of all affected individuals or families with MMs, iACC and DSBS secondary to mutation of DCC. DSBS, absent anterior commissure, absent hippocampal commissure, hypoplastic pons, midline cleft of the brainstem, horizontal gaze palsy and scoliosis; *, small subset of affected individuals from family assessed; $\Delta$, unaffected carrier; ${ }^{\dagger}$, incomplete penetrance; ${ }^{\wedge}$, variable phenotype; -, not recorded. The NP_005206.2 reference sequence is used.

Supp. Table S3 - Overview of individual N-0083-01. Complete ACC, complete agenesis of the corpus callosum; + , incomplete penetrance; ES, exome sequencing; Mono., monoallelic; IgC2, immunoglobulin-like type C2 domain; ExAC, Exome Aggregation Consortium; dbSNP, dbSNP reference SNP identification number. The NM_005215.3 and NP_005206.2 reference sequences are used.

Supp. Table \$4 - Clinical summary of individual N-0083-01. Complete ACC, complete agenesis of the corpus callosum; + , incomplete penetrance; -, not recorded. The NP_005206.2reference sequence is used.

Barr MS, Corballis MC. 2002. The role of the anterior commissure in callosal agenesis. Neuropsychology 16(4):459-71.

Bennett KL, Bradshaw J, Youngman T, Rodgers J, Greenfield B, Aruffo A, Linsley PS. 1997. Deleted in colorectal carcinoma (DCC) binds heparin via its fifth fibronectin type III domain. J Biol Chem 272(43):26940-6.

Bin JM, Han D, Lai Wing Sun K, Croteau LP, Dumontier E, Cloutier JF, Kania A, Kennedy TE. 2015. Complete Loss of Netrin-1 Results in Embryonic Lethality and Severe Axon Guidance Defects without Increased Neural Cell Death. Cell Rep 12(7):1099-106.

Blasiak A, Kilinc D, tee GU. 2017. Neuronal Cell Bodies Remotely Regulate Axonal Growth Response to Localized Netrin-1 Treatment via Second Messenger and DCC Dynamics. Frontiers in Cellular Neuroscience 10(298).

Cesaretti C, Nanni M, Ghi T, Parazzini C, Conte G, Contro E, Grisolia G, Righini A. 2016. Variability of Forebrain Commissures in Callosal Agenesis: A Prenatal MR Imaging Study. AJNR Am J Neuroradiol 37(3):521-7.

Chan SS, Zheng H, Su MW, Wilk R, Killeen MT, Hedgecock EM, Culotti JG. 1996. UNC-40, a C. elegans homolog of DCC (Deleted in Colorectal Cancer), is required in motile cells responding to UNC-6 netrin cues. Cell 87(2):187-195. 
Chan WM, Traboulsi El, Arthur B, Friedman N, Andrews C, Engle EC. 2006. Horizontal gaze palsy with progressive scoliosis can result from compound heterozygous mutations in ROBO3. J Med Genet 43(3):e11.

Chedotal A, Richards LJ. 2010. Wiring the brain: the biology of neuronal guidance. Cold Spring Harb Perspect Biol 2(6):a001917.

Chen Q, Sun X, Zhou X-hH, Liu J-hH, Wu J, Zhang Y, Wang J-hH. 2013. N-terminal horseshoe conformation of DCC is functionally required for axon guidance and might be shared by other neural receptors. Journal of cell science 126(Pt 1):186-195.

Chen Z, Gore BB, Long H, Ma L, Tessier-Lavigne M. 2008. Alternative splicing of the Robo3 axon guidance receptor governs the midline switch from attraction to repulsion. Neuron 58(3):325-32.

Chura LR, Lombardo MV, Ashwin E, Auyeung B, Chakrabarti B, Bullmore ET, Baron-Cohen S. 2010. Organizational effects of fetal testosterone on human corpus callosum size and asymmetry. Psychoneuroendocrinology 35(1):122-32.

Cincotta M, Ragazzoni A, de Scisciolo G, Pinto F, Maurri S, Barontini F. 1994. Abnormal projection of corticospinal tracts in a patient with congenital mirror movements. Neurophysiol Clin 24(6):427-34.

Cincotta M, Ziemann U. 2008. Neurophysiology of unimanual motor control and mirror movements. Clin Neurophysiol 119(4):744-62.

D'Antonio F, Pagani G, Familiari A, Khalil A, Sagies TL, Malinger G, Leibovitz Z, Garel C, Moutard ML, Pilu G, Bhide A, Acharya G, Leombroni M, Manzoli L, Papageorghiou A, Prefumo F. 2016. Outcomes Associated With Isolated Agenesis of the Corpus Callosum: A Meta-analysis. Pediatrics 138(3).

den Dunnen JT, Antonarakis SE. 2000. Mutation nomenclature extensions and suggestions to describe complex mutations: a discussion. Hum Mutat 15(1):7-12.

Depienne C, Bouteiller D, Méneret A, Billot S, Groppa S, Klebe S, Charbonnier-Beaupel F, Corvol J-C, Saraiva J-P, Brueggemann N, Bhatia K, Cincotta M, Brochard V, Flamand-Roze C, Carpentier W, Meunier S, Marie Y, Gaussen M, Stevanin G, Wehrle R, Vidailhet M, Klein C, Dusart I, Brice A, Roze E. 2012. RAD51 haploinsufficiency causes congenital mirror movements in humans. American Journal Of Human Genetics 90(2):301-307.

Depienne C, Cincotta M, Billot S, Bouteiller D, Groppa S, Brochard V, Flamand C, Hubsch C, Meunier S, Giovannelli F, Klebe S, Corvol JC, Vidailhet M, Brice A, Roze E. 2011. A novel DCC mutation and genetic heterogeneity in congenital mirror movements. Neurology 76(3):260-4.

des Portes V, Rolland A, Velazquez-Dominguez J, Peyric E, Cordier MP, Gaucherand P, Massardier J, Massoud M, Curie A, Pellot AS, Rivier F, Lacalm A, Clement A, Ville D, Guibaud L. 2017.

Outcome of isolated agenesis of the corpus callosum: A population-based prospective study. Eur Paediatr Neurol.

Dickson BJ, Zou Y. 2010. Navigating Intermediate Targets: The Nervous System Midline. Cold Spring Harbor Perspectives in Biology 2(8):a002055.

Dominici C, Moreno-Bravo JA, Puiggros SR, Rappeneau Q, Rama N, Vieugue P, Bernet A, Mehlen P, Chédotal A. 2017. Floor-plate-derived netrin-1 is dispensable for commissural axon guidance. Nature 545(7654):350-354.

Dum RP, Strick PL.1991. The origin of corticospinal projections from the premotor areas in the frontal lobe. J Neurosci 11(3):667-89.

Edwards TJ, Sherr EH, Barkovich AJ, Richards LJ. 2014. Clinical, genetic and imaging findings identify new causes for corpus callosum development syndromes. Brain 137(Pt 6):1579-613.

Evans TA, Bashaw GJ. 2010. Axon Guidance at the Midline: Of Mice and Flies. Current opinion in neurobiology 20(1):79-85.

This article is protected by copyright. All rights reserved. 
Fame RM, MacDonald JL, Macklis JD. 2011. Development, Specification, and Diversity of Callosal Projection Neurons. Trends in neurosciences 34(1):41-50.

Fazeli A, Dickinson SL, Hermiston ML, Tighe RV, Steen RG, Small CG, Stoeckli ET, Keino-Masu K, Masu M, Rayburn H, Simons J, Bronson RT, Gordon JI, Tessier-Lavigne M, Weinberg RA. 1997. Phenotype of mice lacking functional Deleted in colorectal cancer (Dcc) gene. Nature 386(6627):796-804.

Fearon ER, Cho KR, Nigro JM, Kern SE, Simons JW, Ruppert JM, Hamilton SR, Preisinger AC, Thomas $\mathrm{G}$, Kinzler KW, et al. 1990. Identification of a chromosome 18q gene that is altered in colorectal cancers. Science 247(4938):49-56.

Finci L, Zhang Y, Meijers R, Wang JH. 2015. Signaling mechanism of the netrin-1 receptor DCC in axon guidance. Prog Biophys Mol Biol 118(3):153-60.

Finci LI, Kruger N, Sun X, Zhang J, Chegkazi M, Wu Y, Schenk G, Mertens HD, Svergun DI, Zhang Y, Wang JH, Meijers R. 2014. The crystal structure of netrin-1 in complex with DCC reveals the bifunctionality of netrin-1 as a guidance cue. Neuron 83(4):839-49.

Finger JH, Bronson RT, Harris B, Johnson K, Przyborski SA, Ackerman SL. 2002. The netrin 1 receptors Unc5h3 and Dcc are necessary at multiple choice points for the guidance of corticospinal tract axons. J Neurosci 22(23):10346-56.

Fokkema IFAC, Taschner PEM, Schaafsma GCP, Celli J, Laros JFJ, den Dunnen JT. 2011. LOVD v.2.0: the next generation in gene variant databases. Human Mutation 32(5):557-563.

Fothergill T, Donahoo A-LS, Douglass A, Zalucki O, Yuan J, Shu T, Goodhill GJ, Richards LJ. 2014. Netrin-DCC Signaling Regulates Corpus Callosum Formation Through Attraction of Pioneering Axons and by Modulating Slit2-Mediated Repulsion. Cerebral Cortex 24(5):1138-1151.

Franz EA, Chiaroni-Clarke R, Woodrow S, Glendining KA, Jasoni CL, Robertson SP, Gardner RJM, Markie D. 2015. Congenital mirror movements: Phenotypes associated with DCC and RAD51 mutations. Journal of the Neurological Sciences 351:140-145.

Friocourt E, Lafont A-G, Kress C, Pain B, Manceau M, Dufour S, Chédotal A. 2017. Recurrent DCC gene losses during bird evolution. Scientific Reports 7:37569.

Geisbrecht BV, Dowd KA, Barfield RW, Longo PA, Leahy DJ. 2003. Netrin binds discrete subdomains ofDCC and UNC5 and mediates interactions between DCC and heparin. J Biol Chem 278(35):32561-8.

Gobius I, Morcom L, Suárez R, Bunt J, Bukshpun P, Reardon W, Dobyns William B, Rubenstein John LR, Barkovich AJ, Sherr Elliott H, Richards Linda J. 2016. Astroglial-Mediated Remodeling of the Interhemispheric Midline Is Required for the Formation of the Corpus Callosum. Cell Reports 17(3):735-747.

Grandin M, Meier M, Delcros JG, Nikodemus D, Reuten R, Patel TR, Goldschneider D, Orriss G, Krahn N, Boussouar A, Abes R, Dean Y, Neves D, Bernet A, Depil S, Schneiders F, Poole K, Dante R, Koch M, Mehlen P, Stetefeld J. 2016. Structural Decoding of the Netrin-1/UNC5 Interaction and its Therapeutical Implications in Cancers. Cancer Cell 29(2):173-85.

Guirland C, Suzuki S, Kojima M, Lu B, Zheng JQ. 2004. Lipid rafts mediate chemotropic guidance of nerve growth cones. Neuron 42(1):51-62.

Harada H, Sato T, Nakamura H. 2016. Fgf8 signaling for development of the midbrain and hindbrain. Development, Growth \& Differentiation 58(5):437-445.

Harter PN, Bunz B, Dietz K, Hoffmann K, Meyermann R, Mittelbronn M. 2010. Spatio-temporal deleted in colorectal cancer (DCC) and netrin-1 expression in human foetal brain development. Neuropathol Appl Neurobiol 36(7):623-35.

Harwell CG, Parker PR, Gee SM, Okada A, McConnell SK, Kreitzer AC, Kriegstein AR. 2012. Sonic hedgehog expression in corticofugal projection neurons directs cortical microcircuit formation. Neuron 73(6):1116-26.

This article is protected by copyright. All rights reserved. 
Hayhurst M, Gore BB, Tessier-Lavigne M, McConnell SK. 2008. Ongoing sonic hedgehog signaling is required for dorsal midline formation in the developing forebrain. Dev Neurobiol 68(1):83100.

Hedrick $\perp$, Cho KR, Fearon ER, Wu TC, Kinzler KW, Vogelstein B. 1994. The DCC gene product in celtular differentiation and colorectal tumorigenesis. Genes Dev 8(10):1174-83.

Herincs Z, Corset V, Cahuzac N, Furne C, Castellani V, Hueber AO, Mehlen P. 2005. DCC association with lipid rafts is required for netrin-1-mediated axon guidance. J Cell Sci 118(Pt 8):1687-92.

Hetts SW, Sherr EH, Chao S, Gobuty S, Barkovich AJ. 2006. Anomalies of the corpus callosum: an MR analysis of the phenotypic spectrum of associated malformations. AJR Am J Roentgenol 18z(5):1343-8.

Holley JA. 1982. Early development of the circumferential axonal pathway in mouse and chick spinal cord. J Comp Neurol 205(4):371-82.

Hong K, Hinck L, Nishiyama M, Poo MM, Tessier-Lavigne M, Stein E. 1999. A ligand-gated association between cytoplasmic domains of UNC5 and DCC family receptors converts netrin-induced growth cone attraction to repulsion. Cell 97(7):927-41.

Jamuar SS, Schmitz-Abe K, D'Gama AM, Drottar M, Chan WM, Peeva M, Servattalab S, Lam AN, Delgado MR, Clegg NJ, Zayed ZA, Dogar MA, Alorainy IA, Jamea AA, Abu-Amero K, Griebel M, Ward W, Lein ES, Markianos K, Barkovich AJ, Robson CD, Grant PE, Bosley TM, Engle EC, Walsh CA, Yu TW. 2017. Biallelic mutations in human DCC cause developmental split-brain syndrome. Nat Genet 49(4):606-612.

Jen JC. 2008. Effects of failure of development of crossing brainstem pathways on ocular motor control. Prog Brain Res 171:137-41.

Jen JC, Chan WM, Bosley TM, Wan J, Carr JR, Rub U, Shattuck D, Salamon G, Kudo LC, Ou J, Lin DD, Salih MA, Kansu T, Al Dhalaan H, AI Zayed Z, MacDonald DB, Stigsby B, Plaitakis A, Dretakis EK, Gottlob I, Pieh C, Traboulsi El, Wang Q, Wang L, Andrews C, Yamada K, Demer JL, Karim S, Alger JR, Geschwind DH, Deller T, Sicotte NL, Nelson SF, Baloh RW, Engle EC. 2004. Mutations in a human ROBO gene disrupt hindbrain axon pathway crossing and morphogenesis. Science 304(5676):1509-13.

Jouan L, Ouled Amar Bencheikh B, Daoud H, Dionne-Laporte A, Dobrzeniecka S, Spiegelman D, Rochefort D, Hince P, Szuto A, Lassonde M, Barbelanne M, Tsang WY, Dion PA, Theoret $H$, Rouleau GA. 2016. Exome sequencing identifies recessive CDK5RAP2 variants in patients with isolated agenesis of corpus callosum. Eur J Hum Genet 24(4):607-610.

Kahn OI, Baas PW. 2016. Microtubules and Growth Cones: Motors Drive the Turn. Trends in Neurosciences 39(7):433-440.

Keays DA, Tian G, Poirier K, Huang GJ, Siebold C, Cleak J, Oliver PL, Fray M, Harvey RJ, Molnar Z, Pinon MC, Dear N, Valdar W, Brown SD, Davies KE, Rawlins JN, Cowan NJ, Nolan P, Chelly J, Flint J. 2007. Mutations in alpha-tubulin cause abnormal neuronal migration in mice and lissencephaly in humans. Cell 128(1):45-57.

Keino-Masu K, Masu M, Hinck L, Leonardo ED, Chan SS, Culotti JG, Tessier-Lavigne M. 1996. Deleted in Colorectal Cancer (DCC) encodes a netrin receptor. Cell 87(2):175-185.

Keleman K, Dickson BJ. 2001. Short- and Long-Range Repulsion by the Drosophila Unc5 Netrin Receptor. Neuron 32(4):605-617.

Kennedy TE, Serafini T, de la Torre JR, Tessier-Lavigne M. 1994. Netrins are diffusible chemotropic factors for commissural axons in the embryonic spinal cord. Cell 78(3):425-35.

Kennedy TE, Wang H, Marshall W, Tessier-Lavigne M. 2006. Axon Guidance by Diffusible Chemoattractants: A Gradient of Netrin Protein in the Developing Spinal Cord. The Journal of Neuroscience 26(34):8866-8874.

Koester SE, O'Leary DD. 1994. Axons of early generated neurons in cingulate cortex pioneer the corpus callosum. J Neurosci 14(11 Pt 1):6608-20.

This article is protected by copyright. All rights reserved. 
Kolodziej PA, Timpe LC, Mitchell KJ, Fried SR, Goodman CS, Jan LY, Jan YN. 1996. frazzled encodes a Drosophila member of the DCC immunoglobulin subfamily and is required for CNS and motor axon guidance. Cell 87(2):197-204.

Kuker W, Mayrhofer H, Mader I, Nagele T, Krageloh-Mann I. 2003. Malformations of the midline commissures: MRI findings in different forms of callosal dysgenesis. Eur Radiol 13(3):598604

Leonardo ED, Hinck L, Masu M, Keino-Masu K, Ackerman SL, Tessier-Lavigne M. 1997. Vertebrate homologues of C. elegans UNC-5 are candidate netrin receptors. Nature(6627):833.

Li W, Aurandt J, Jürgensen C, Rao Y, Guan K-L. 2006. FAK and Src kinases are required for netrininduced tyrosine phosphorylation of UNC5. Journal of Cell Science 119(1):47-55.

Li W, Lee J, Vikis HG, Lee S-H, Liu G, Aurandt J, Shen T-L, Fearon ER, Guan J-L, Han M, Rao Y, Hong K, Guan K-L. 2004. Activation of FAK and Src are receptor-proximal events required for netrin signaling. Nature neuroscience 7(11):1213-1221.

Li X, Meriane M, Triki I, Shekarabi M, Kennedy TE, Larose L, Lamarche-Vane N. 2002. The adaptor protein Nck-1 couples the netrin-1 receptor DCC (deleted in colorectal cancer) to the activation of the small GTPase Rac1 through an atypical mechanism. The Journal Of Biological Chemistry 277(40):37788-37797.

Liu G, Beggs H, Jürgensen C, Park H-T, Tang H, Gorski J, Jones KR, Reichardt LF, Wu J, Rao Y. 2004. Netrin requires focal adhesion kinase and Src family kinases for axon outgrowth and attraction. Nature neuroscience 7(11):1222-1232.

Llambi F, Causeret F, Bloch-Gallego E, Mehlen P. 2001. Netrin-1 acts as a survival factor via its receptors UNC5H and DCC. Embo j 20(11):2715-22.

Luo L. 2002. Actin cytoskeleton regulation in neuronal morphogenesis and structural plasticity. Annu Rev Cell Dev Biol 18:601-35.

MacArthur JA, Morales J, Tully RE, Astashyn A, Gil L, Bruford EA, Larsson P, Flicek P, Dalgleish R, Maglott DR, Cunningham F. 2014. Locus Reference Genomic: reference sequences for the reporting of clinically relevant sequence variants. Nucleic Acids Res 42(Database issue):D873-8.

Marillat V, Sabatier C, Failli V, Matsunaga E, Sotelo C, Tessier-Lavigne M, Chedotal A. 2004. The slit receptor Rig-1/Robo3 controls midline crossing by hindbrain precerebellar neurons and axons. Neuron 43(1):69-79.

Marsh AP, Heron D, Edwards TJ, Quartier A, Galea C, Nava C, Rastetter A, Moutard ML, Anderson V, Bitoun P, Bunt J, Faudet A, Garel C, Gillies G, Gobius I, Guegan J, Heide S, Keren B, Lesne F, Luki $V$, Mandelstam SA, McGillivray G, Mcllroy A, Meneret A, Mignot C, Morcom LR, Odent $S$, Paolino A, Pope K, Riant F, Robinson GA, Spencer-Smith M, Srour M, Stephenson SE, Tankard R, Trouillard O, Welniarz Q, Wood A, Brice A, Rouleau G, Attie-Bitach T, Delatycki MB, Mandel JL, Amor DJ, Roze E, Piton A, Bahlo M, Billette de Villemeur T, Sherr EH, Leventer RJ, Richards LJ, Lockhart PJ, Depienne C. 2017. Mutations in DCC cause isolated agenesis of the corpus callosum with incomplete penetrance. Nat Genet 49(4):511-514.

Méneret A, Depienne C, Riant F, Trouillard O, Bouteiller D, Cincotta M, Bitoun P, Wickert J, Lagroua I, Westenberger A, Borgheresi A, Doummar D, Romano M, Rossi S, Defebvre L, De Meirleir L, Espay AJ, Fiori S, Klebe S, Quélin C, Rudnik-Schöneborn S, Plessis G, Dale RC, Sklower Brooks S, DziezycK, Pollak P, Golmard J-L, Vidailhet M, Brice A, Roze E. 2014a. Congenital mirror movements: Mutational analysis of RAD51 and DCC in 26 cases. Neurology 82(22):19992002.

Méneret A, Franz EA, Trouillard O, Oliver TC, Zagar Y, Robertson SP, Welniarz Q, Gardner RJM, Gallea $C$, Srour M, Depienne C, Jasoni CL, Dubacq C, Riant F, Lamy J-C, Morel M-P, Guérois R, Andreani J, Fouquet C, Doulazmi M, Vidailhet M, Rouleau GA, Brice A, Chédotal A, Dusart I,

This article is protected by copyright. All rights reserved. 
Roze E, Markie D. 2017. Mutations in the netrin-1 gene cause congenital mirror movements. The Journal of Clinical Investigation 127(11).

Meneret A, Trouillard O, Brochard V, Roze E. 2015. Congenital mirror movements caused by a mutation in the DCC gene. Dev Med Child Neurol 57(8):776.

Méneret A,Trouillard O, Vidailhet M, Depienne C, Roze E. 2014b. Congenital mirror movements: no mutation in DNAL4 in 17 index cases. p 2030-2031.

Meriane M, Tcherkezian J, Webber CA, Danek El, Triki I, McFarlane S, Bloch-Gallego E, LamarcheVane N. 2004. Phosphorylation of DCC by Fyn mediates Netrin-1 signaling in growth cone guidance. The Journal of Cell Biology 167(4):687-698.

Mille F, Llambi F, Guix C, Delloye-Bourgeois C, Guenebeaud C, Castro-Obregon S, Bredesen DE, Thibert $C$, Mehlen P. 2009. Interfering with multimerization of netrin-1 receptors triggers turnor cell death. Cell Death Differ 16(10):1344-51.

Moffat SD, Hampson E, Wickett JC, Vernon PA, Lee DH. 1997. Testosterone is correlated with regional morphology of the human corpus callosum. Brain Res 767(2):297-304.

Molyneaux BJ, Arlotta P, Menezes JRL, Macklis JD. 2007. Neuronal subtype specification in the cerebral cortex. Nat Rev Neurosci 8(6):427-437.

Nathan PW, Smith MC, Deacon P. 1990. The corticospinal tracts in man. Course and location of fibres at different segmental levels. Brain 113 ( Pt 2):303-24.

Norris AD, Sundararajan L, Morgan DE, Roberts ZJ, Lundquist EA. 2014. The UNC-6/Netrin receptors UNC-40/DCC and UNC-5 inhibit growth cone filopodial protrusion via UNC-73/Trio, Rac-like GTPases and UNC-33/CRMP. Development 141(22):4395-4405.

Okada T, OkumuraY, Motoyama J, Ogawa M. 2008. FGF8 signaling patterns the telencephalic midline by regulating putative key factors of midline development. Dev Biol 320(1):92-101.

Parrish ML, Roessmann U, Levinsohn MW. 1979. Agenesis of the corpus callosum: a study of the frequency of associated malformations. Ann Neurol 6(4):349-54.

Paul LK, Brown WS, Adolphs R, Tyszka JM, Richards LJ, Mukherjee P, Sherr EH. 2007. Agenesis of the corpus callosum: genetic, developmental and functional aspects of connectivity. Nat Rev Neurosci 8(4):287-99.

Rabe Bernhardt N, Memic F, Gezelius H, Thiebes AL, Vallstedt A, Kullander K. 2012. DCC mediated axon guidance of spinal interneurons is essential for normal locomotor central pattern generator function. Dev Biol 366(2):279-89.

Raper J, Mason C. 2010. Cellular strategies of axonal pathfinding. Cold Spring Harb Perspect Biol 2(9):a001933.

Rapp B, Perrotin F, Marret H, Sembely-Taveau C, Lansac J, Body G. 2002. [Value of fetal cerebral magnetic resonance imaging for the prenatal diagnosis and prognosis of corpus callosum agenesis\}. J Gynecol Obstet Biol Reprod (Paris) 31(2 Pt 1):173-82.

Rash BG, Richards LJ. 2001. A role for cingulate pioneering axons in the development of the corpus callosum. J Comp Neurol 434(2):147-57.

Ren T, Anderson A, Shen WB, Huang H, Plachez C, Zhang J, Mori S, Kinsman SL, Richards L. 2006. Imaging, anatomical, and molecular analysis of callosal formation in the developing human fetal brain. Anat Rec A Discov Mol Cell Evol Biol 288(2):191-204.

Ren XR, Hong Y, Feng Z, Yang HM, Mei L, Xiong WC. 2008. Tyrosine phosphorylation of netrin receptors in netrin-1 signaling. Neurosignals 16(2-3):235-45.

Ren XR, Ming GL, Xile Y, Hong Y, Sun DM, Zhao ZQ, Feng Z, Wang Q, Shim S, Chen ZF, Song HJ, Mei L, Xiong WC. 2004. Focal adhesion kinase in netrin-1 signaling. Nat Neurosci 7(11):1204-12.

Renier N, Schonewille M, Giraudet F, Badura A, Tessier-Lavigne M, Avan P, De Zeeuw Cl, Chedotal A. 2010. Genetic dissection of the function of hindbrain axonal commissures. PLoS Biol 8(3):e1000325.

This article is protected by copyright. All rights reserved. 
Sabatier C, Plump AS, Le M, Brose K, Tamada A, Murakami F, Lee EYHP, Tessier-Lavigne M. 2004. The Divergent Robo Family Protein Rig-1/Robo3 Is a Negative Regulator of Slit Responsiveness Required for Midline Crossing by Commissural Axons. Cell 117(2):157-169.

Serafini I, Colamariho SA, Leonardo ED, Wang H, Beddington R, Skarnes WC, Tessier-Lavigne M. 1996. Netrin-1 is required for commissural axon guidance in the developing vertebrate nervous system. Cell 87(6):1001-14.

Serafini T, Kennedy TE, Galko MJ, Mirzayan C, Jessell TM, Tessier-Lavigne M. 1994. The netrins define a family of axon outgrowth-promoting proteins homologous to $C$. elegans UNC-6. Cell 78(3):409-24.

Sharafaddinzadeh N, Bavarsad R, Yousefkhah M, Aleali A. 2008. Familial mirror movements over five generations. Neurology India(4).

Shu T, Li Y, Keller A, Richards LJ. 2003. The glial sling is a migratory population of developing neurons. Development (Cambridge, England) 130(13):2929-2937.

Shu T, Richards $\downarrow$. 2001. Cortical Axon Guidance by the Glial Wedge during the Development of the Corpus Callosum. The Journal of Neuroscience 21(8):2749-2758.

Shu T, Valentino KM, Seaman C, Cooper HM, Richards LJ. 2000. Expression of the Netrin-1 receptor, deleted in colorectal cancer (DCC), is largely confined to projecting neurons in the developing forebrain. The Journal of Comparative Neurology 416(2):201-212.

Sicotte NL, Salamon G, Shattuck DW, Hageman N, Rub U, Salamon N, Drain AE, Demer JL, Engle EC, Alger JR, Baloh RW, Deller T, Jen JC. 2006. Diffusion tensor MRI shows abnormal brainstem crossing fibers associated with ROBO3 mutations. Neurology 67(3):519-21.

Silver J, Lorenz SE, Wahlsten D, Coughlin J. 1982. Axonal guidance during development of the great cerebral commissures: descriptive and experimental studies, in vivo, on the role of preformed glial pathways. J Comp Neurol 210(1):10-29.

Sotiriadis A, Makrydimas G. 2012. Neurodevelopment after prenatal diagnosis of isolated agenesis of the corpus callosum: an integrative review. Am J Obstet Gynecol 206(4):337.e1-5.

Srour M, Philibert M, Dion MH, Duquette A, Richer F, Rouleau GA, Chouinard S. 2009. Familial congenitat mirror movements: report of a large 4-generation family. Neurology 73(9):729-

\section{1.}

Srour M, Rivière J-BB, Pham JM, Dubé M-PP, Girard S, Morin S, Dion PA, Asselin G, Rochefort D, Hince P, Diab S, Sharafaddinzadeh N, Chouinard S, Théoret H, Charron F, Rouleau GA. 2010. Mutations in DCC cause congenital mirror movements. Science (New York, N.Y.) 328(5978):592.

Stein E, Tessier-Lavigne M. 2001. Hierarchical organization of guidance receptors: silencing of netrin attraction by slit through a Robo/DCC receptor complex. Science 291(5510):1928-38.

Stein E, Zou Y,Poo M, Tessier-Lavigne M. 2001. Binding of DCC by netrin-1 to mediate axon guidance independent of adenosine A2B receptor activation. Science 291(5510):1976-82.

Tercanli S, Prufer F. 2016. Fetal Neurosonogaphy: Ultrasound and Magnetic Resonance Imaging in Competition. Ultraschall Med 37(6):555-557.

Tessier-Lavigne M, Goodman CS. 1996. The molecular biology of axon guidance. Science 274(5290):1123-33.

Tessier-Lavigne M, Placzek M, Lumsden AG, Dodd J, Jessell TM. 1988. Chemotropic guidance of developing axons in the mammalian central nervous system. Nature 336(6201):775-8.

Unni DK, Piper M, Moldrich RX, Gobius I, Liu S, Fothergill T, Donahoo A-LS, Baisden JM, Cooper HM, Richards LJ. 2012. Multiple Slits regulate the development of midline glial populations and the corpus callosum. Developmental Biology 365(1):36-49.

Varadarajan SG, Butler SJ. 2017. Netrin1 establishes multiple boundaries for axon growth in the developing spinal cord. Dev Biol 430(1):177-187.

This article is protected by copyright. All rights reserved. 
Varadarajan SG, Kong JH, Phan KD, Kao TJ, Panaitof SC, Cardin J, Eltzschig H, Kania A, Novitch BG, Butler SJ. 2017. Netrin1 Produced by Neural Progenitors, Not Floor Plate Cells, Is Required for Axon Guidance in the Spinal Cord. Neuron 94(4):790-799.e3.

Welniarz Q, Dusart I, Gallea C, Roze E. 2015. One hand clapping: lateralization of motor control. Frontiers in Neuroanatomy 9:75.

Welniarz Q, Dusart I, Roze E. 2017a. The corticospinal tract: Evolution, development, and human disorders. Developmental Neurobiology 77(7):810-829.

Welniarz Q, Morel MP, Pourchet O, Gallea C, Lamy JC, Cincotta M, Doulazmi M, Belle M, Meneret A, Trouillard O, Ruiz M, Brochard V, Meunier S, Trembleau A, Vidailhet M, Chedotal A, Dusart I, Roze E. 2017b. Non cell-autonomous role of DCC in the guidance of the corticospinal tract at the midline. Sci Rep 7(1):410.

Williams ME, Lu X, McKenna WL, Washington R, Boyette A, Strickland P, Dillon A, Kaprielian Z, Tessier-Lavigne M, Hinck L. 2006. UNC5A promotes neuronal apoptosis during spinal cord development independent of netrin-1. Nat Neurosci 9(8):996-8.

Woods BT, Teuber HL. 1978. Mirror movements after childhood hemiparesis. Neurology 28(11):1152-1157.

Wright C, Sibley CP, Baker PN. 2010. The role of fetal magnetic resonance imaging. Arch Dis Child Fetal Neonatal Ed 95(2):F137-41.

Xu K, Wu Z, Renier N, Antipenko A, Tzvetkova-Robev D, Xu Y, Minchenko M, Nardi-Dei V, Rajashankar KR, Himanen J, Tessier-Lavigne M, Nikolov DB. 2014. Structures of Netrin-1 Bound to two Receptors Provide Insight into its Axon Guidance Mechanism. Science (New York, N.Y.) 344(6189):1275-1279.

Yamauchi K, Yamazaki M, Abe M, Sakimura K, Lickert H, Kawasaki T, Murakami F, Hirata T. 2017. Netrin-1 Derived from the Ventricular Zone, but not the Floor Plate, Directs Hindbrain Commissural Axons to the Ventral Midline. Scientific Reports 7(1):11992.

Yee KT, Simon HH, Tessier-Lavigne M, O'Leary DM. 1999. Extension of long leading processes and neuronal migration in the mammalian brain directed by the chemoattractant netrin-1. Neuron 24(3):607-22.

Zelina P, Blockus H, Zagar Y, Peres A, Friocourt F, Wu Z, Rama N, Fouquet C, Hohenester E, TessierLavigne M, Schweitzer J, Roest Crollius H, Chedotal A. 2014. Signaling switch of the axon guidance receptor Robo3 during vertebrate evolution. Neuron 84(6):1258-72.

Zhou J, Wen Y, She L, Sui Y-n, Liu L, Richards LJ, Poo M-m. 2013. Axon position within the corpus callosum determines contralateral cortical projection. Proceedings of the National Academy of Sciences 110(29):E2714-E2723.

This article is protected by copyright. All rights reserved. 
Table 1 - Overview of all reported DCC mutations linked to MMs, iACC and DSBS. DSBS, developmental split brain syndrome; CACC, complete isolated agenesis of the corpus callosum; PACC, partial isolated agenesis of the corpus callosum; MMs, mirror movements; $\Delta$, unaffected carrier; + , incomplete penetrance; ES, exome sequencing; SEQ, direct sequencing of DCC; Hom.; homozygosity mapping; ${ }^{*}$, inferred transmission of mutant allele; Bi., biallelic; Mono., monoallelic; IgC2, immunoglobulin-like type C2 domain; FN3, fibronectin type III-like domain; ExAC, Exome Aggregation Consortium; dbSNP, dbSNP reference SNP identification number. The NM_005215.3 and NP_005206.2 reference sequences are used.

\begin{tabular}{|c|c|c|c|c|c|c|c|c|c|c|c|c|}
\hline $\begin{array}{l}\text { Fa } \\
\text { mil } \\
y\end{array}$ & $\begin{array}{l}\text { Phen } \\
\text { otype }\end{array}$ & $\begin{array}{ll}\text { No. Sex } \\
\text { of } \\
\text { ffe } \text { affe } \\
\text { ted }\end{array}$ & $\begin{array}{l}\text { Variant } \\
\text { identifi } \\
\text { cation }\end{array}$ & $\begin{array}{l}\text { Inherita } \\
\text { nce } \\
\text { (transm } \\
\text { ission) }\end{array}$ & All & $\begin{array}{l}\text { Ex } \\
\text { on } \\
/ \\
\text { int } \\
\text { ron }\end{array}$ & cDNA & Protein & $\begin{array}{l}\text { Pro } \\
\text { tein } \\
\text { do } \\
\text { mai } \\
\text { n }\end{array}$ & ExAC & dbSNP & $\begin{array}{c}\text { Referenc } \\
\text { e }\end{array}$ \\
\hline 1 & $\begin{array}{c}\text { DSBS } \\
\Delta\end{array}$ & $2 \mathrm{M}$ & $\begin{array}{c}\text { Hom. + } \\
\text { SEQ }\end{array}$ & $\begin{array}{c}\text { Germlin } \\
\text { e } \\
\text { (both)* }\end{array}$ & Bi. & 1 & $\begin{array}{c}\text { c.31_91+76 } \\
22 \mathrm{del}\end{array}$ & $\begin{array}{l}\text { p.(Pro11Th } \\
\text { rfs*15) }\end{array}$ & - & - & - & $\begin{array}{c}\text { Jamuar et } \\
\text { al. } 2017\end{array}$ \\
\hline 2 & MMs & M & SEQ & $\begin{array}{l}\text { Germlin } \\
\text { e } \\
\text { (patern } \\
\text { al) }\end{array}$ & $\begin{array}{l}\text { Mo } \\
\text { no. }\end{array}$ & 2 & c. $377 \mathrm{C}>\mathrm{A}$ & p. $\left(\operatorname{Ser} 126^{*}\right)$ & $\begin{array}{l}\operatorname{lgC} 2 \\
-1\end{array}$ & - & - & $\begin{array}{l}\text { Meneret } \\
\text { et al. } \\
2014\end{array}$ \\
\hline 3 & $\begin{array}{c}\text { MMs } \\
+\end{array}$ & $1 \mathrm{M}$ & SEQ & $\begin{array}{l}\text { Germlin } \\
\text { e } \\
\text { (matern } \\
\text { al) }\end{array}$ & $\begin{array}{l}\text { Mo } \\
\text { no. }\end{array}$ & 3 & c. $527 A>G$ & $\begin{array}{c}\text { p.(Asn176S } \\
\text { er) }\end{array}$ & $\begin{array}{l}\operatorname{lgC} 2 \\
-2\end{array}$ & $\begin{array}{c}5 / 121 \\
228\end{array}$ & $\begin{array}{c}\text { rs13872 } \\
4679\end{array}$ & $\begin{array}{l}\text { Meneret } \\
\text { et al. } \\
2014\end{array}$ \\
\hline 4 & $\begin{array}{c}\text { MMs } \\
+\end{array}$ & $\mathrm{M}$ & SEQ & $\begin{array}{c}\text { Germlin } \\
\text { e } \\
\text { (either) } \\
*\end{array}$ & $\begin{array}{l}\text { Mo } \\
\text { no. }\end{array}$ & 3 & c.571dupG & $\begin{array}{l}\text { p.(Val191G } \\
\text { lyfs*35) }\end{array}$ & $\begin{array}{l}\operatorname{lgC2} \\
-2\end{array}$ & - & - & $\begin{array}{c}\text { Sharafad } \\
\text { dinzadeh } \\
\text { et al. } \\
2008 \\
\text { Srour et } \\
\text { al. } 2010\end{array}$ \\
\hline 5 & MMs & $1 F$ & SEQ & $\begin{array}{l}\text { Unkno } \\
\text { wn } \\
\text { (unkno } \\
\text { wn) }\end{array}$ & $\begin{array}{l}\text { Mo } \\
\text { no. }\end{array}$ & $3 i_{-}$ & $\begin{array}{c}\text { c. }(697+1 \text { 6 } \\
98-1) \_ \\
(985+1 \text {-98 } \\
\text { 6-1)del }\end{array}$ & $\begin{array}{l}\text { p.(Asp233+ } \\
?+\begin{array}{l}\text { Leu328- } \\
\text { ?del) }\end{array}\end{array}$ & $\begin{array}{l}\operatorname{lgC2} \\
-3\end{array}$ & - & - & $\begin{array}{c}\text { Borghere } \\
\text { si et al. } \\
2010 \\
\text { Meneret } \\
\text { et al. } \\
2014\end{array}$ \\
\hline 6 & $\begin{array}{c}\text { DSBS } \\
\Delta\end{array}$ & & SEQ & $\begin{array}{c}\text { Germlin } \\
\text { e } \\
\text { (both) }\end{array}$ & Bi. & 4 & $\begin{array}{c}\text { c.788_794d } \\
\text { el }\end{array}$ & $\begin{array}{c}\text { p.(Val263Al } \\
\text { afs*36) }\end{array}$ & $\begin{array}{l}\operatorname{lgC2} 2 \\
-3\end{array}$ & - & - & $\begin{array}{c}\text { Jamuar et } \\
\text { al. } 2017\end{array}$ \\
\hline 7 & $\begin{array}{l}\text { cACC } \\
\text { or } \\
\text { MMs } \\
\pm \\
\text { pACC } \\
+\end{array}$ & $\begin{array}{l}3 \mathrm{M}: \\
4 \mathrm{~F}\end{array}$ & SEQ & $\begin{array}{l}\text { Germlin } \\
\text { e } \\
\text { (either) } \\
*\end{array}$ & $\begin{array}{l}\text { Mo } \\
\text { no. }\end{array}$ & 4 & c. $823 \mathrm{C}>\mathrm{T}$ & p.(Arg275* & $\begin{array}{c}\operatorname{lgC} 2 \\
-3\end{array}$ & - & - & $\begin{array}{c}\text { Meneret } \\
\text { et al. } \\
2014 \\
\text { Marsh et } \\
\text { al. } 2017 \\
\text { Welniarz } \\
\text { et al. } \\
2017\end{array}$ \\
\hline 8 & $\begin{array}{l}\mathrm{MM} \pm \\
\mathrm{pACC}\end{array}$ & $2 \mathrm{~F}$ & SEQ & $\begin{array}{l}\text { Germlin } \\
\text { e } \\
\text { (either) }\end{array}$ & $\begin{array}{l}\text { Mo } \\
\text { no. }\end{array}$ & 4 & c. $823 C>T$ & p.(Arg $275^{*}$ & $\begin{array}{c}\lg C 2 \\
-3\end{array}$ & - & - & $\begin{array}{l}\text { Meneret } \\
\text { et al. } \\
2014 \\
\text { Meneret } \\
\text { et al. } \\
2015 \\
\text { Welniarz } \\
\text { et al. } \\
2017\end{array}$ \\
\hline 9 & $\begin{array}{l}\text { cACC } \\
\text { or } \\
\text { pACC }\end{array}$ & $5 F$ & $\begin{array}{c}\text { Linkage } \\
+\mathrm{ES}+ \\
\text { SEQ }\end{array}$ & $\begin{array}{l}\text { Germlin } \\
\text { e } \\
\text { (either) }\end{array}$ & $\begin{array}{l}\text { Mo } \\
\text { no. }\end{array}$ & 5 & c. 925 delA & $\begin{array}{l}\text { p. (Thr309P } \\
\text { rofs*26) }\end{array}$ & $\begin{array}{l}\operatorname{lgC} 2 \\
-3\end{array}$ & - & - & $\begin{array}{l}\text { Marsh et } \\
\text { al. } 2017\end{array}$ \\
\hline
\end{tabular}

This article is protected by copyright. All rights reserved. 


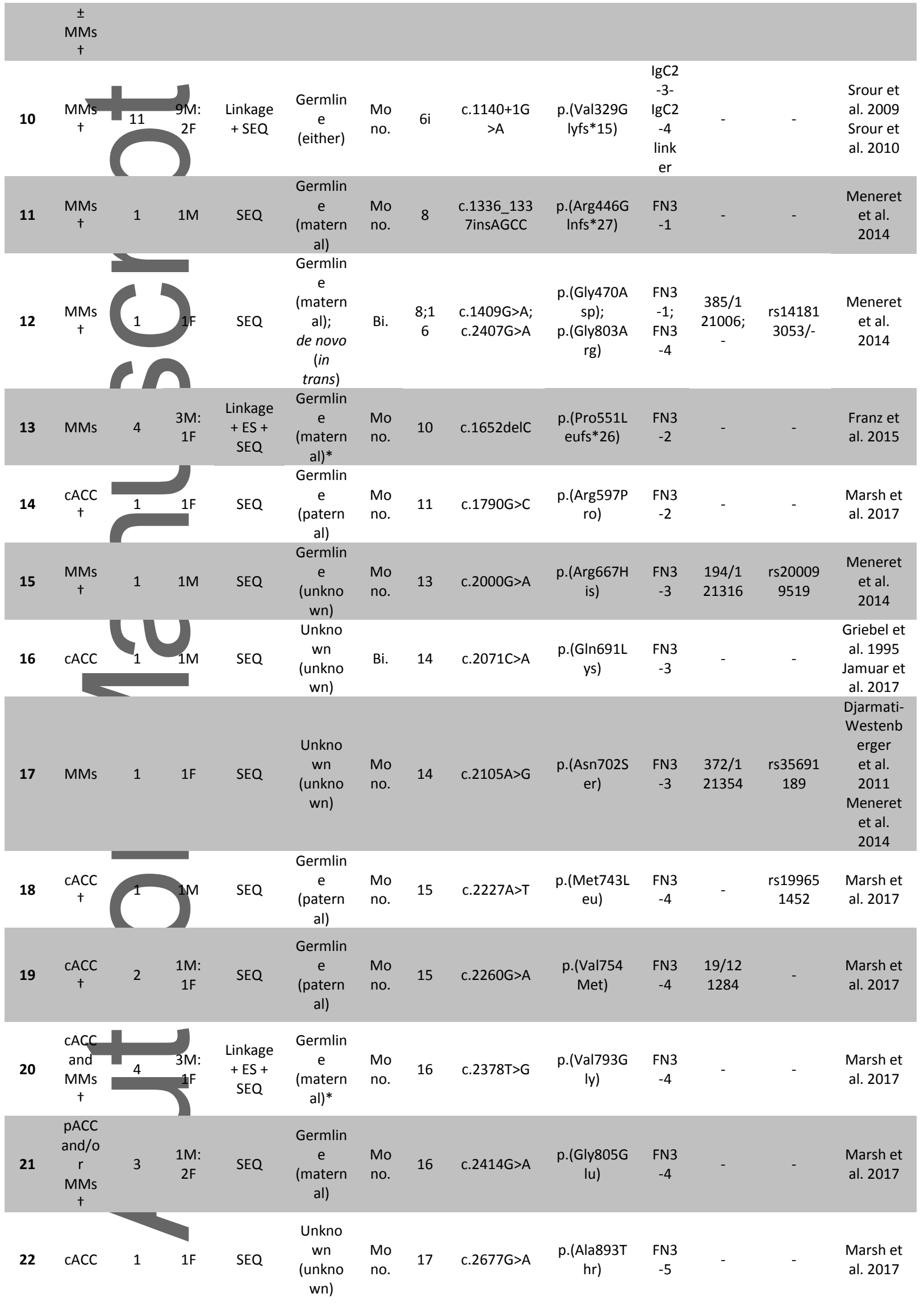

This article is protected by copyright. All rights reserved. 


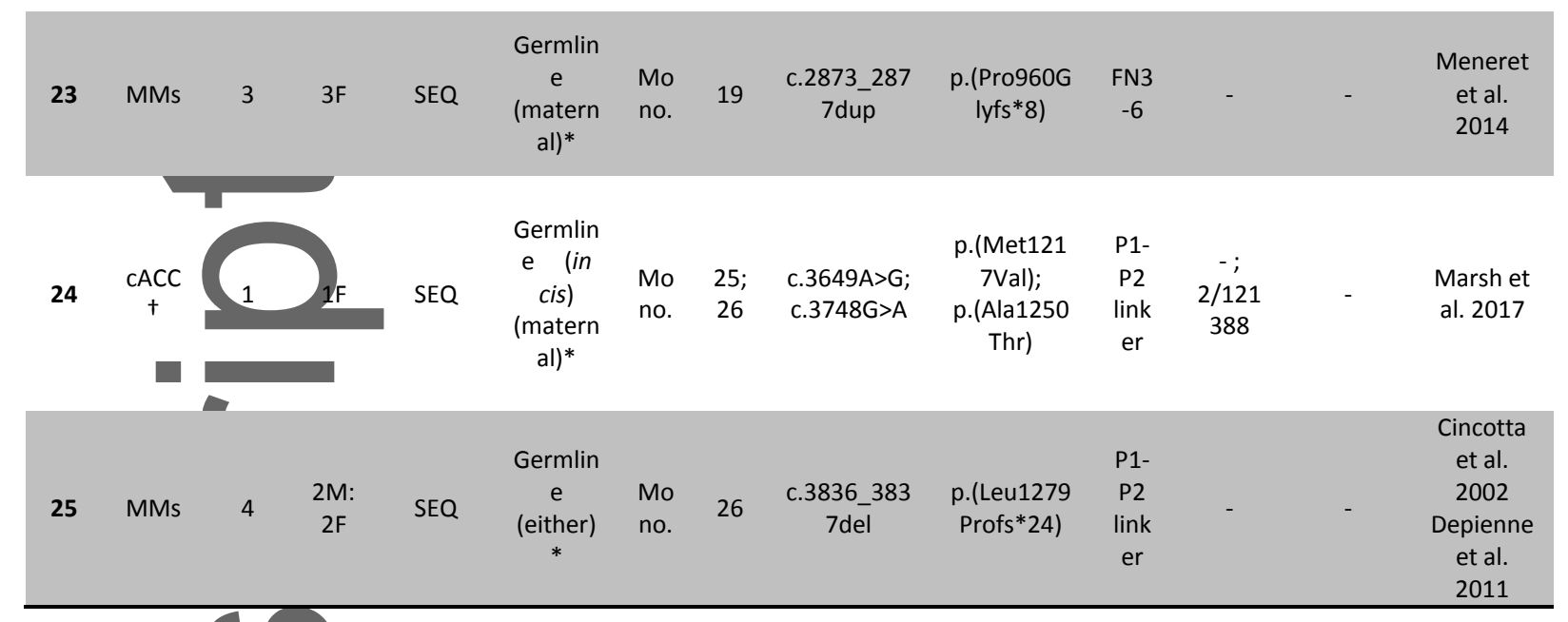

\section{Figure and Table Legends}

Figure 1 - Linear $D C C$ gene schematic with protein domain structure depicting the location of all reported mutations. Square, predicted loss-of-function; circle, missense mutation; red, DSBS; green, MMS; blue, iACC; orange, MMs and iACC. The NTN1 binding region is indicated. IgC2, immunoglobulin-like type C2 domain; FN3, fibronectin type III-like domain; TM, transmembrane domain; P1-3, conserved P motifs. The NP_005206.2 reference sequence is used. Image modified from Marsh et al. 2017.
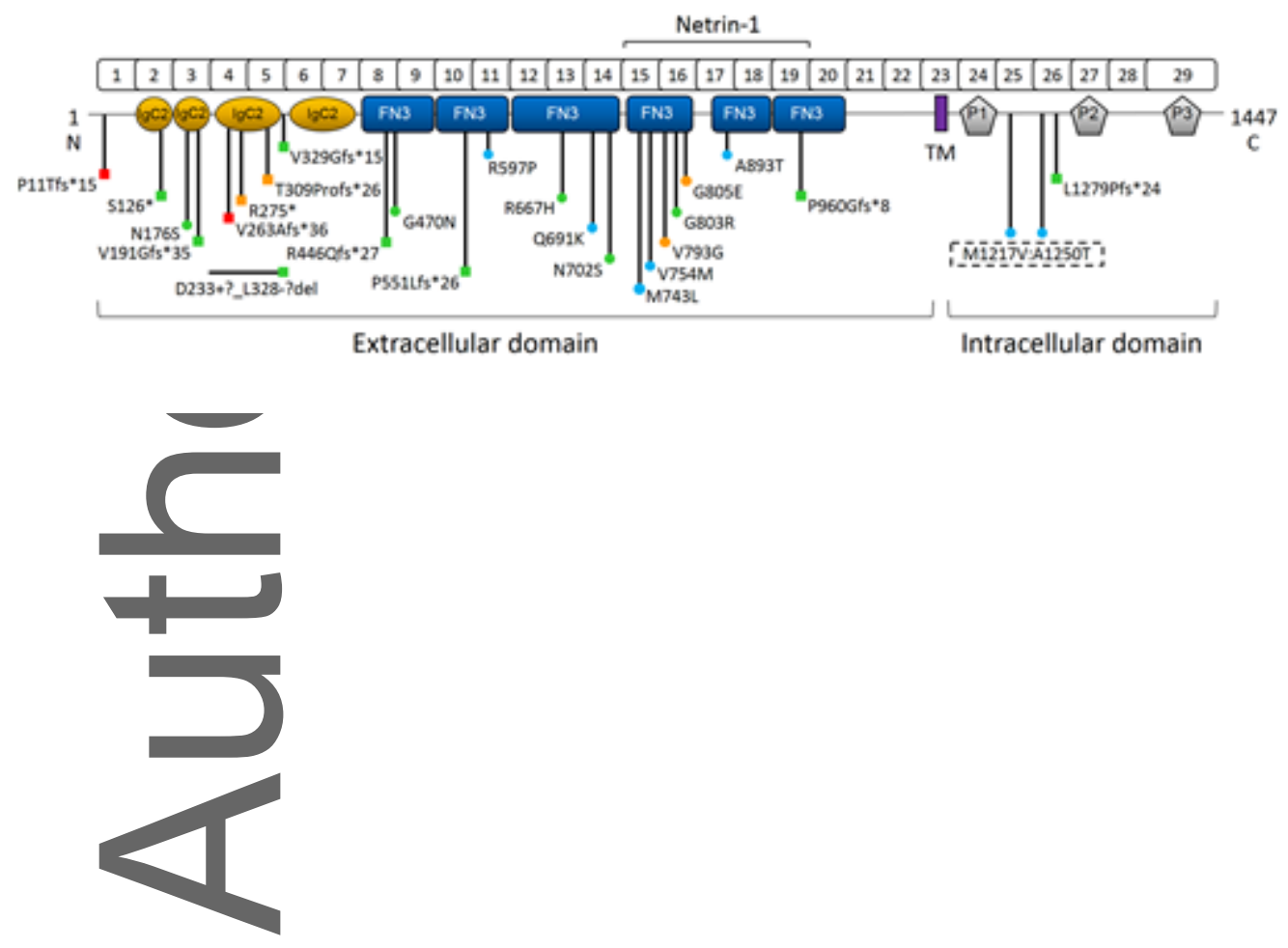

This article is protected by copyright. All rights reserved. 
Figure 2 - (A) Schematic drawing of DCC with protein domain structure depicting the location of the NTN1 binding sites (BS) 0,1 and 2. (B) Structure of NTN1 protein depicting the location of its DCC binding sites BSO, BS1 and BS2. (C) NTN1 residues (colored spheres) that bind the $4^{\text {th }}$ and $5^{\text {th }}$ FN3 domains of DCC (green and yellow ribbons, respectively) are conserved throughout evolution. Conserved residues are colored red, non-conserved residues are colored blue. IgC2, immunoglobulin-like type C2 domain; FN3, fibronectin type III-like domain, P1-3, conserved P motifs; NTR, netrin-like domain; LE, laminin-type epidermal growth factor-like domain; LN, laminin-like domain.

A

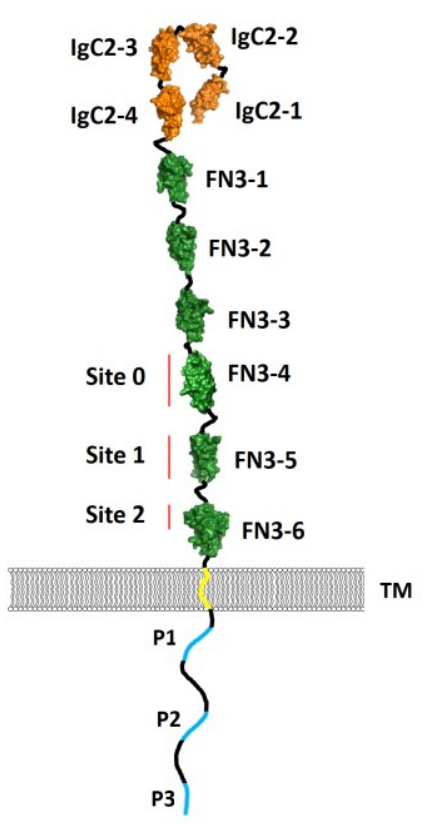

B

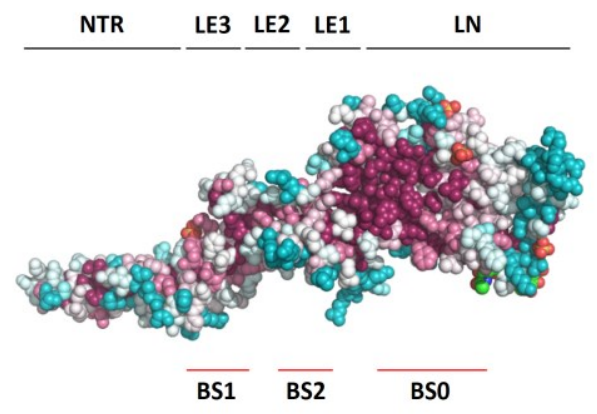

C
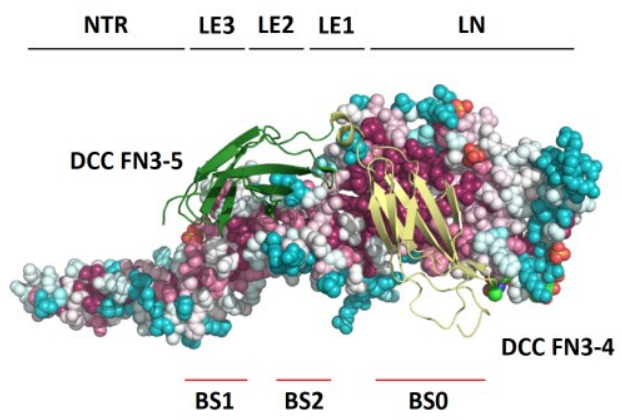

This article is protected by copyright. All rights reserved. 
Figure 3 - (A) Binding site 1 (BS1) and BS2 of the NTN1/DCC complex (PDB ID: 4URT). (B) Binding site 2 (BS2) of the NTN1/DCC complex (PDB ID: 4URT). (C) Binding site 0 (BSO) of the NTN1/DCC complex (PDB ID: 4PLO). Structure of NTN1 (transparent molecular surface) bound to DCC FN3 domains (orange ribbons). The expansion of the red dotted box region shows the NTN1 (magenta sticks) and DCC (gray or white sticks) involved in binding at BS1, BS2 or BSO. Hydrogen bonds are represented by dotted black lines. FN3, fibronectin type IIIlike domain; PDB ID, Protein Data Bank identification.
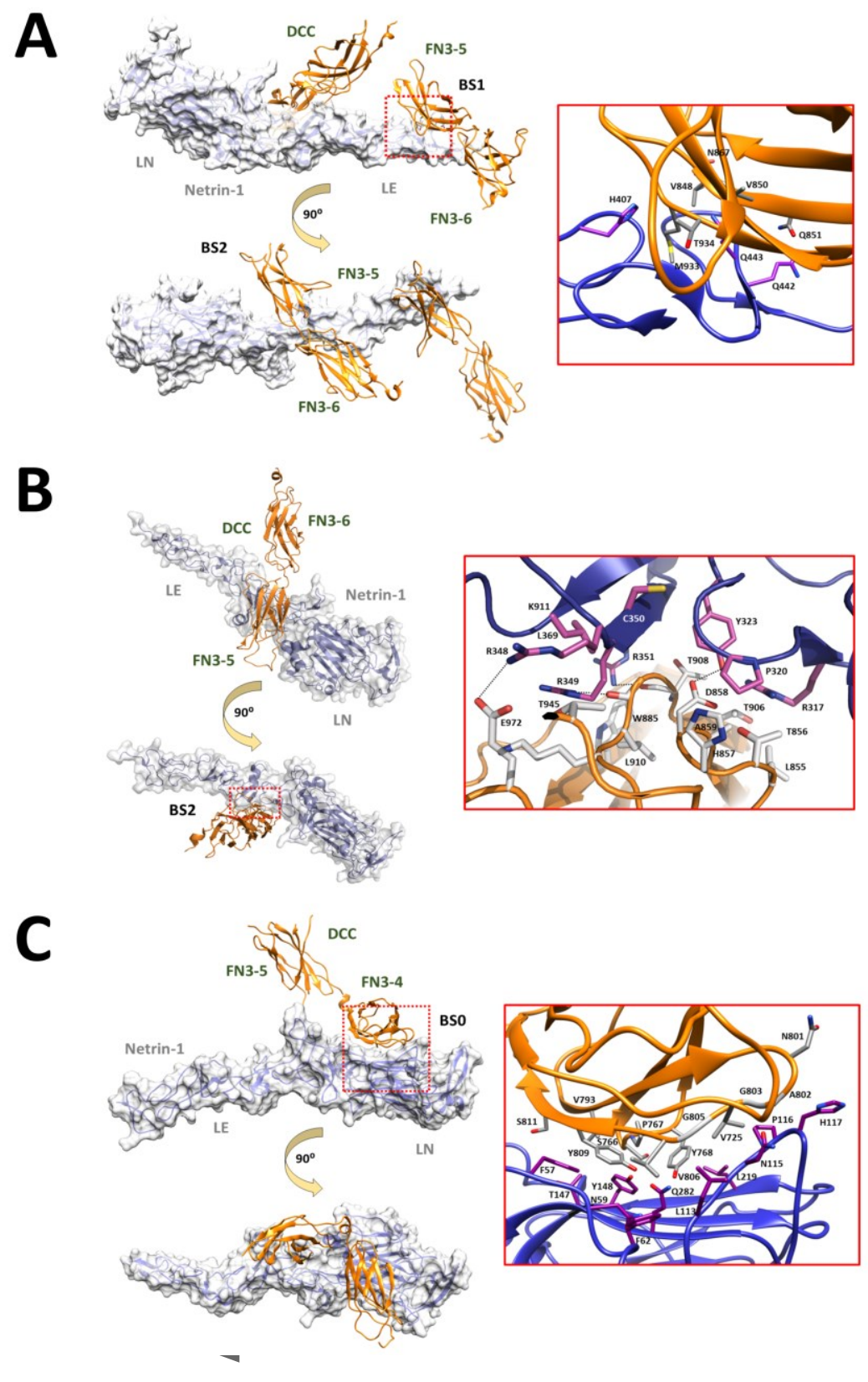

This article is protected by copyright. All rights reserved. 
Figure 4 - The fibronectin type III-like (FN3) domains are required for NTN1 binding and DCC function. (A) Enrichment of DCC missense mutations linked to MMs and/or iACC within the NTN1 binding region. Structure of NTN1/DCC complex. DCC is depicted as an orange ribbon and NTN1 as a white solvent accessible surface. DCC missense mutations located within the FN3-4 and FN3-5 domains are represented as blue spheres (PDB ID: 4PLO). (B) Expansion of the binding interface (red dotted box in A) with NTN1 residues colored blue and critical DCC residues represented as purple sticks. Mutation of V793 and G805 to Gly and Glu, respectively, is associated with both MMs and iACC. (C) Sequence alignment of the DCC FN3 domains. Residues highlighted in green are predicted to be directly involved in NTN1 binding by Finci et al. 2014 and/or Xu et al. 2014. Residues in yellow are missense mutations associated with MMs and/or iACC. Residues in blue are missense mutations associated with MMs and/or iACC that are also predicted to be directly involved in NTN1 binding. The NP_005206.2 reference sequence is used. PDB ID, Protein Data Bank identification. Image modified from Marsh et al. 2017.

A

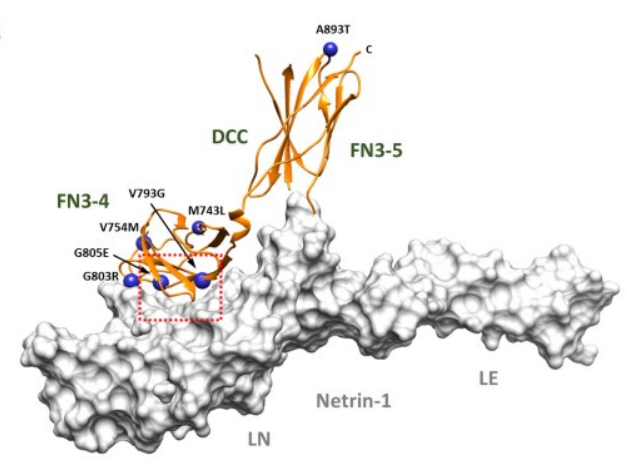

B

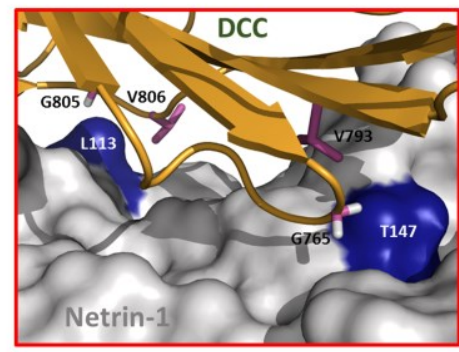

C
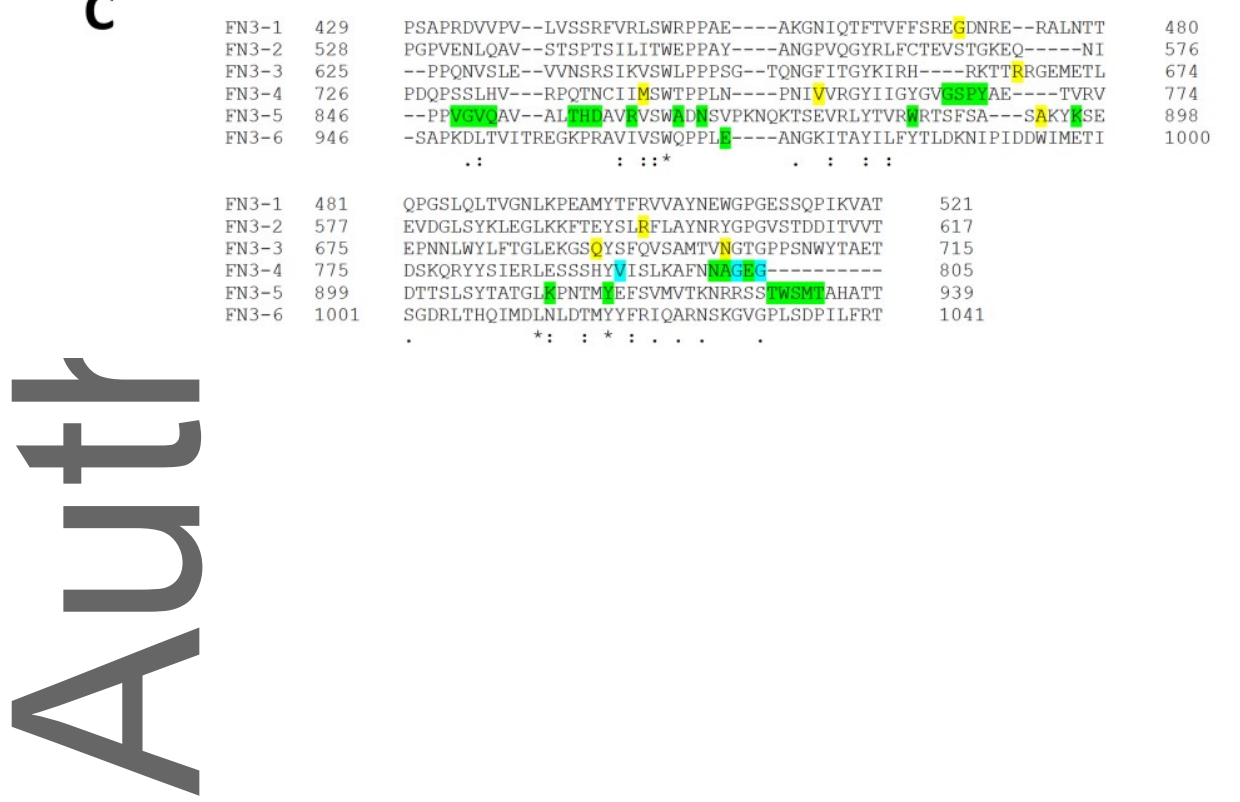

GDRLTHQIMDI $*: \quad: \quad: \quad$.

This article is protected by copyright. All rights reserved. 
Figure 5 - Axial MRI of control $(\mathrm{A})$ and individuals with complete $D C C$-iACC (D), partial $D C C$ iACC (G) and DSBS (J). Midsagittal MRI of control (B) and individuals with complete DCC-iACC $(E)$, partial DCC-iACC with absence of the rostrum and genu $(\mathrm{H})$ and DSBS (K). Coronal MRI of control (C) and individuals with complete DCC-iACC (F), partial DCC-iACC (I) and DSBS (L). iACC, isolated agenesis of the corpus callosum; DSBS, developmental split brain syndrome. Images A-( adapted from Marsh et al. 2017. Images J-L adapted from Jamuar et al. 2017.
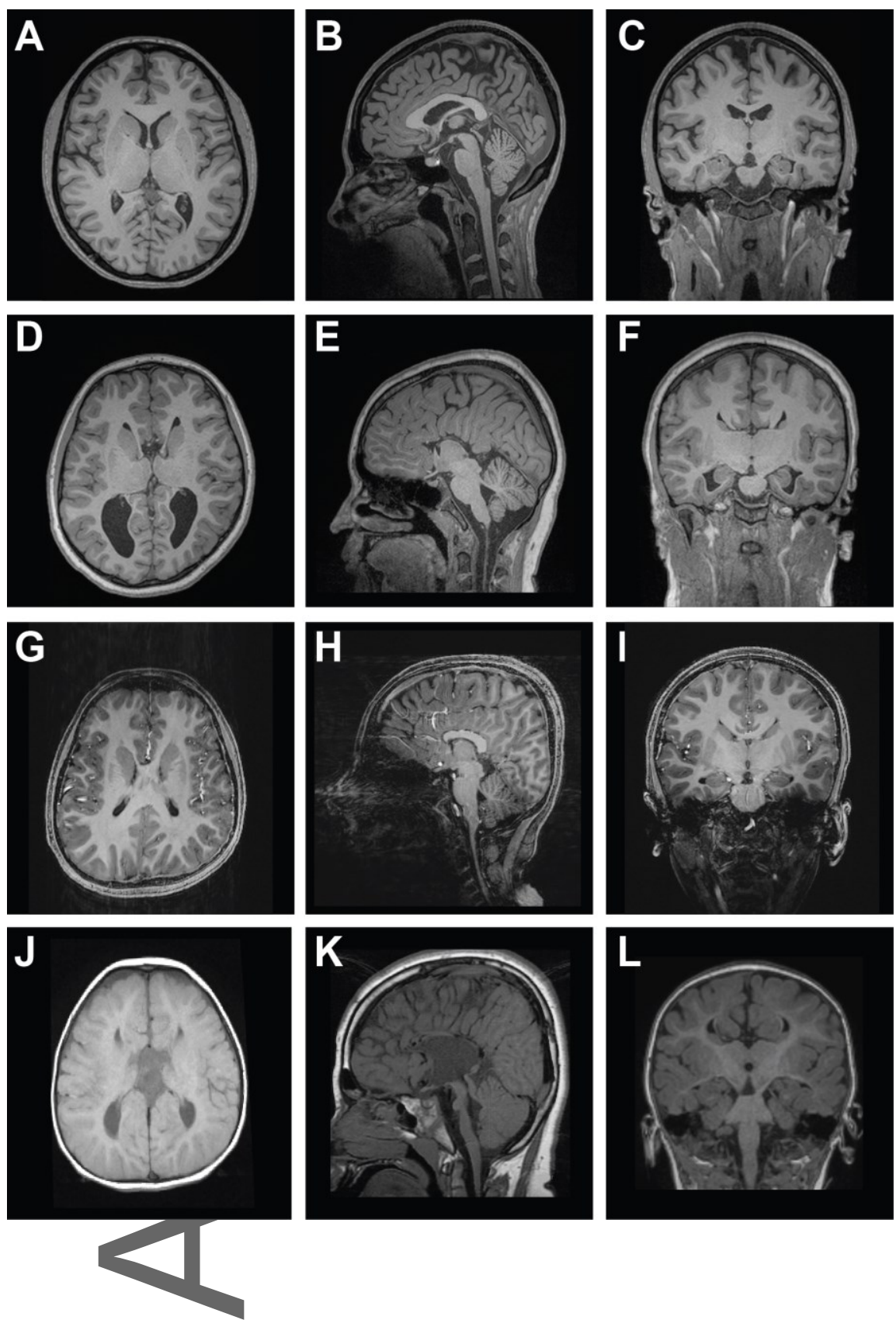

This article is protected by copyright. All rights reserved. 


\section{University Library}

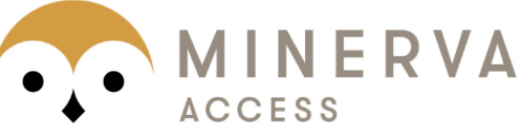

A gateway to Melbourne's research publications

Minerva Access is the Institutional Repository of The University of Melbourne

\section{Author/s:}

Marsh, APL;Edwards, TJ;Galea, C;Cooper, HM;Engle, EC;Jamuar, SS;Meneret, A;Moutard, M-L;Nava, C;Rastetter, A;Robinson, G;Rouleau, G;Roze, E;Spencer-Smith, M;Trouillard, O;Billette de Villemeur, T;Walsh, CA;Yu, TW;Heron, D;Sherr, EH;Richards, LJ;Depienne, C;Leventer, RJ;Lockhart, PJ

Title:

DCC mutation update: Congenital mirror movements, isolated agenesis of the corpus callosum, and developmental split brain syndrome

Date:

2018-01-01

\section{Citation:}

Marsh, A. P. L., Edwards, T. J., Galea, C., Cooper, H. M., Engle, E. C., Jamuar, S. S., Meneret, A., Moutard, M. -L., Nava, C., Rastetter, A., Robinson, G., Rouleau, G., Roze, E., Spencer-Smith, M., Trouillard, O., Billette de Villemeur, T., Walsh, C. A., Yu, T. W., Heron, D. ,... Lockhart, P. J. (2018). DCC mutation update: Congenital mirror movements, isolated agenesis of the corpus callosum, and developmental split brain syndrome. HUMAN MUTATION, 39 (1), pp.23-39. https://doi.org/10.1002/humu.23361.

Persistent Link:

http://hdl.handle.net/11343/293848 